\title{
Internationalization And Profitability Of The U.S. Multinational Companies After The Free Trade Agreement
}

Ayse Yuce, Ryerson University, Canada

Sergiy Rakhmanyil, Ryerson University, Canada

\begin{abstract}
This paper examines the effect of North American liberalization on the degree of internationalization and profitability of US companies using industry-level data between 1985 and 2005. We find evidence of long-run increases in the degree of internationalization and evidence pointing at increases in firm profitability in the short and long run for US companies following the introduction of NAFTA. We find cross-sectional variation in the degree of internationalization and profitability for US industry sectors. Overall, our results indicate that the process of liberalization has had a positive impact on both the degree of internationalization and on firm profitability for US companies.
\end{abstract}

Keywords: NAFTA; liberalization; multinational firm performance

\section{INTRODUCTION}

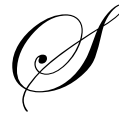

tarting in the 1980's, improvement in information technology and reduction of tariffs and other legal barriers of trade increased globalization and liberalization of international trade. Multinational companies took advantage of liberalization and increased their export and import activities.

The North American Free Trade Agreement, which was implemented in 1994, offers a unique chance to study the effects of liberalization on company performance. Proponents of free trade agreements argue that NAFTA should increase trade among three countries, increase competition, and create benefits for both the consumers and the companies by reducing tariffs, regulations and making markets accessible for all companies in three countries. On the other hand, opponents fear that small- and medium-size local companies will suffer because they cannot compete with large multinational companies without protection provided by their governments.

This paper investigates whether or not reduction of tariffs increased the liberalization of company performances and their profitability. We examine the effects of liberalization introduced by NAFTA on company performance and profitability. The paper starts with review of previous studies in the first section. The second section introduces data, and the third section focuses on methodology and the hypotheses. We discuss results in the fourth section and summarize our findings in the conclusion.

\section{PREVIOUS STUDIES}

Effect of NAFTA on company performances is not investigated as extensively as that of on equity index levels. The following studies examine various aspects of firm performance during and after NAFTA agreement. Ghani and Haverty (1995) investigates the stock market reaction associated with the passage of the North American Free Trade Agreement (NAFTA) for firms that cited NAFTA as a favorable development in the Management Discussion and Analysis on the president's letter to the shareholders sections of their annual reports to show that significant positive average abnormal returns for a sample of firms which expressed favorable views. In contrast, no significant average abnormal and average cumulative abnormal returns performances were documented for the 
industry-matched control group. Aggarwal, Moore, Long, and Ervin (1998) conclude that NAFTA significantly increases returns for a broad sample of 1,471 firms. The study also documents significant industry variations in the firm value impact of NAFTA. Companies in chemicals and machinery industry groups benefit the most and those in automotive products and telecommunication experience significant wealth declines. Hanson and Song (1998) show that, on average, shareholders of U.S. firms neither gained nor lost from the passage of NAFTA, but shareholders of Mexican firms experienced significant gains.

Baggs and Brander (2006) find that the net effect of the NAFTA in Canada was to increase profits and reduce leverage. Thompson's 1994 results suggest that Canadian investors anticipated natural resource-intensive firms to benefit relative to capital-intensive firms. The results of Rodriguez's 2003 paper about investor expectations in three countries show that investors consistently rewarded manufacturing sectors on the basis of simple factor intensity. The results do not support the existence of a significant relationship between profits, trade liberalization, and the relative scales of production industries in NAFTA countries.

Different studies find conflicting results about the effect of NAFTA on company profitability and on shareholder returns. It is time to investigate the relationship between liberalization and internationalization and secondly between liberalization and company performance after the introduction of NAFTA in a comprehensive study. This paper examines and compares U.S. multinational company performance, profitability, employment and valuation before and after the introduction of NAFTA.

\section{DATA}

In order to investigate the effect of liberalization on the degree of internationalization and profitability for U.S. companies, we collect balance sheet and income statement data from S\&P Compustat between 1985 and 2005. We used the introduction of NAFTA in 1994 as a reference point (year 0) and study whether there were significant short run changes in the degree of internationalization between year -1 and year +3 , and what long-term changes took place between year -1 and year +11 . We include public companies incorporated in the USA that have available observations in 1993, 1994, and 1997 or 2005 . We stipulate this condition because we plan to study within-firm changes during the liberalization process and thus need firm data both before and after the implementation of NAFTA.

We collect data on Net Income, Total Assets, Sales, Shareholders' Equity, Federal Income Taxes, Foreign Income Taxes, Domestic Pretax Income, Foreign Pretax Income, and industry classification codes for the firms. We use these data to construct two proxies for the degree of internationalization: DOIINC and DOITAX. Variable DOIINC is defined as Foreign Pretax Income (Foreign Pretax Income + Domestic Pretax Income). Variable DOITAX is defined as Foreign Income Taxes (Foreign Income Taxes + Federal Income Taxes). These proxy variables are used in the existing literature, for example, in Chen et al (1997). We also construct three proxy variables for firm profitability: Return on Sales (ROS), Return on Assets (ROA), and return on equity (ROE).

We compute changes in the internationalization and profitability proxies between 1993 (year -1) and 1997 (year +3$)$ and between 1993 (year -1) and 2005 (year +11 ). To ensure that our results are meaningful and they are not driven by outliers, we exclude from analysis those companies with negative pretax income and negative taxes, foreign or domestic. We also exclude companies in the top and bottom 5\% of profitability changes. We have, very large in absolute value, extreme observations that skew the distribution of the profitability changes; for example; 1993-2005 change in return on assets (ROA) for the USA ranges from -19.85 to 13.62 , with skewness -10.29 and kurtosis 510.69. If we eliminate the outliers, the variable ranges from -0.38 to 0.43 , with skewness -0.04 and kurtosis 6.59. The extreme observations affect mean changes, but not median changes, which are expected since medians are, by construction, less influenced by the outliers. The empirical tests produce similar results with or without the outliers and are available upon request from the authors. Our final sample consists of 4,725 firms for the 1993-1997 period and 2,084 firms for the 1993-2005 period. 


\section{HYPOTHESES}

Economic theory views the liberalization process as a method of reduction of risk, increasing use of comparative advantage, economies of scale, and subsequent economic growth. See, for example, Obstfeld (1994) and Thompson (1994) or Grabowski and Shields (1996) who offer a comprehensive survey of free trade and protectionist arguments. It implies that firms should display a greater degree of internationalization and better financial performance after cross-border transaction costs are reduced by such events as implementation of NAFTA. Opponents of liberalization, on the other hand, argue that reduction of import tariffs should hurt local companies because it will expose them to harsher competition from overseas.

Trade liberalization is expected to have a positive effect on the degree of international activity for all firms. Exporting firms will benefit from lower export tariffs because their products will have a better competitive position in the overseas markets. Next, importing firms will benefit from lower import tariffs as their products will now have a better competitive position in the local markets. Firms that did not have international involvement may see new opportunities and engage in such activities. We investigate whether or not the data supports this hypothesis.

In theory, a reduction of transaction costs, including the types of transaction costs removed by NAFTA and similar trade agreements, should lead to better use of resources. This might mean that very inefficient firms may have to discontinue operations or lay off workers because of greater international competition and more efficient firms or firms in different industry sectors will benefit. Thus, at least in the short run, one may expect employment to decrease. Alternatively, if the trade liberalization leads to greater utilization of comparative advantage rather than resource reallocation, then firms will have greater demand for their products and will hire more workers to meet the demand.

Firm value is a function of future cash flows and the cost of capital. The overall effect of the liberalization process is expected to be larger cash flows for firms that benefit from lower transaction costs, and lower cost of capital resulting from financial liberalization. In the end, we expect to see the increase in firm values. Conversely, firms vulnerable to greater foreign competition may experience lower cash flows and greater cost of capital and, consequently, lower values. To compare market valuation for firms of different sizes, we use Tobin's Q ratios. We examine whether a greater degree of liberalization increases or decreases the Tobin's Q for companies in our sample. In Table I, we present the summary of hypotheses examined in this study.

We will test the following hypotheses. First, we study whether the degree of firm internationalization, measured by DOIINC and DOITAX, increased since implementation of NAFTA. Second, we investigate whether, during the same time, firms improved their profitability, measured by ROS, ROA, and ROE. Then we will examine whether employment has decreased and whether company values had increased after the free trade agreement. We expect to observe improvements in the firm internationalization and profitability in the short run, between 1993 and 1997. We expect that more firms will be able to adjust their production processes to the new liberalized environment in the long run, thus we expect to observe profound increases in internalization and profitability between 1993 and 2005 .

\section{METHODOLOGY}

\section{Univariate Analysis}

To conduct univariate analysis, we use the nonparametric methodology, similar to the one employed earlier by Megginson, Nash and van Randenborgh (1994), and study whether the liberalization process resulted in significant changes in the degree of internationalization and profitability for companies in our sample. Megginson, Nash and van Randenborgh (1994) designed a methodology to analyze the effect of privatization on firm performance. This methodology has been successfully used in studying changes in firm performance in the literature. Its key advantages are simplicity and robustness to outliers in the data. We use this methodology because it ideally fits our purpose of studying changes in firm performance in the USA following regulatory changes for cross-border transactions as a result of NAFTA. 
To test theoretical predictions, we compute proxy variables for each firm between 1993 (year -1) and 1997 (year +3 ) for the short-term and between 1993 (year -1) and 2005 (year +11$)$ for the long-term analysis. Next, we use Wilcoxon/Mann-Whitney test to examine whether there are significant median changes in company performance measures for the whole sample of US companies, and for each industry sector, including, Materials, Consumer Discretionary, Consumer Staples, Health Care, Energy, Financials, Industrials, Information Technology, Telecommunication Services, and Utilities. We also use a proportion test to find out whether the proportion of the firms that have predicted performance changes is significantly different from 0.5 , which would be expected if firms changed performance just by chance. If, on the other hand, we find that a large proportion of firms changed performance in a given direction, this evidence may be helpful in understanding the effects of North American liberalization processes on firm performance.

Next, we conduct regression-based tests. We estimate the following equation:

$$
V_{i, t}=\sum_{\text {industry } y=1}^{10} \beta_{1, i} I_{i}\left(1-D_{t}\right)+\beta_{2, i} I_{i} D_{t}+e_{i, t}
$$

where $\mathrm{V}$ is variable of interest (ROS, ROA, ROE, DOIINC, DOTAX, Employees, or Tobin's Q), $\mathrm{I}_{\mathrm{i}}$ denote dummies for each industry sector $i, \mathrm{i}=1, \ldots, 10$, dummy variable $\mathrm{D}_{\mathrm{t}}$ equals 0 before 1994 and 1 after $1994, \beta_{1, \mathrm{i}}$ and $\beta_{2, \mathrm{i}}$ are regression coefficients, and $\mathrm{e}_{\mathrm{i}, \mathrm{t}}$ are regression residuals.

Equation (1) is a regression on the mean; therefore, $\beta_{1, \mathrm{i}}$ estimates pre-1994 mean values and $\beta_{2, \mathrm{i}}$ is the post1994 mean values for each of the firm performance variables for each industry sector. The equations are estimated using panel least squares method across all firms for the 1985-2005 period. To study the effect of liberalization on profitability, degree of internationalization, employment, and market valuation, we test the hypothesis that for each industry $i$ mean values are equal across the sub-samples. We test the null hypothesis to see whether or not pre NAFTA ratio means (ROS, ROA, ROE, DOIINC, DOTAX, Employees and Tobin's Q) are equal to post-NAFTA ratio means.

\section{Multivariate Analysis}

In order to examine the effect of NAFTA on a firm's performance, we estimate a pooled least squares regression model for 1985-2005. The dependent variable is a measure of firm performance. The indicator variable NAFTA has a value of 0 before 1994 and a value of 1 after 1994. The model has the following specification

$$
P_{i, t}=\gamma X_{i, t}+\delta Y_{t}+\lambda N A F T A_{t}+\varepsilon_{i, c, t},
$$

where $\gamma$ is a vector of coefficients for firm characteristics $\mathrm{X}_{\mathrm{i}, \mathrm{t}}$, and $\delta$ is a vector of coefficients for the macroeconomic variables $Y_{t}$. The effect of NAFTA on firm performance is estimated by coefficient $\lambda$, and $\varepsilon_{i, c, t}$ is regression residual. The standard errors are computed using the diagonal White method.

The firm characteristics variables include industry dummies, lagged leverage $\mathrm{LEV}_{\mathrm{t}-1}$, the measure of firm size as the natural logarithm of lagged total assets $\operatorname{LOG}\left(\mathrm{TA}_{\mathrm{t}-1}\right)$, standard deviation of Net Income over the previous three years normalized by last year's sales, SDS. The economic variables, all lagged one year, include inflation, annual real GDP growth rate RGDPG, annualized yield on three months' government securities SRATE, a term structure variable TS defined as the difference between long-term government bond yield and short-term interest rate on government securities, and the default premium DP defined as the difference between yields on BBB and AAA rated corporate bonds.

To examine the effect of NAFTA on individual industry sectors, we estimate a model that includes firm performance as the dependent variable, and products of industry dummies and NAFTA as independent variables, together with firm characteristics and country characteristics variables 


$$
P_{i, t}=\gamma X_{i, t}+\delta Y_{t}+\sum_{\forall k} \phi_{k} I_{k, i} N A F T A+\varsigma_{i, t},
$$

where $\varphi_{\mathrm{k}}$ is a coefficient that represents the estimated effect of the Euro on industry $\mathrm{k}, \mathrm{I}_{\mathrm{k}}$ is an industry dummy, and $\varsigma_{\mathrm{i}, \mathrm{c}, \mathrm{t}}$ is regression residual. The industries include Oil \& Gas, Basic Materials, Industrials, Consumer Goods, Health Care, Consumer Services, Telecommunications, Utilities, Financials, and Technology.

Finally, to study the effect of NAFTA on firms with specific characteristics such as size, we estimate a model that includes firm performance as the dependent variable, and products of firm characteristics and NAFTA as independent variables, together with all control variables:

$$
P_{i, t}=\gamma X_{i, t}+\delta Y_{t}+\lambda N A F T A_{t}+\sum_{\forall i} \theta_{i} \tilde{X}_{i} N A F T A+\varepsilon_{i, c, t},
$$

where $\gamma$ is a vector of coefficients for firm characteristics $\mathrm{X}_{\mathrm{i}, \mathrm{t}}$, and $\delta$ is a vector of coefficients for the macroeconomic variables $Y_{t}$. The effect of NAFTA on firm performance is estimated by coefficient $\lambda$, and by coefficients $\theta_{i}$ for the interaction of dummy variable NAFTA and each company specific information variable $\tilde{X}_{i}$. Finally, $\varepsilon_{\mathrm{i}, \mathrm{c}, \mathrm{t}}$ is regression residual. The standard errors are computed using the diagonal White method. We estimate coefficients $\theta_{i}$ for each variable separately and for all of them together.

\section{RESULTS}

\section{Univariate Analysis}

\section{Median Equality Test Results}

We first consider short-term changes in the degree of internationalization and profitability between 1993 and 1997. Next, we discuss long-term changes in the proxy variables between 1993 and 2005. In general, we find no evidence of improvement in the degree of internationalization in the short-term, but we do find significant evidence of improvements in firm profitability. Our long-term analysis brings to light significant improvements in both the degree of internationalization and profitability. We also find cross-sectional variation in the results for different industry sectors. Overall, our results indicate that the process of liberalization has had positive impact on both the degree of internationalization and on firm profitability for US companies.

\section{Degree of Internationalization}

The first hypothesis is related to the degree of internationalization. The liberalization process in North America included reduction in transaction costs, including import and export tariffs, as a part of free trade agreements, such as NAFTA. A reduction in transaction costs should, in theory, improve access to foreign markets, thus it should lead to a greater degree of internationalization for domestic companies. We measure internationalization with two proxies: the proportion of foreign pretax income in total pretax income DOINC and the proportion of foreign tax in the sum of foreign and federal tax DOITAX. We can see that the two proxies display a long-term trend towards increase but this increase is gradual and contains short-term downward fluctuations.

Table II displays results of median equality tests of the internationalization measures between 1993 and 1997. For the whole sample median, DOIINC increased from 0.1956 to 0.2241 , but this increase is insignificant, with corresponding $\mathrm{p}$-value of 0.1415 . The proportion of firms that increased DOIINC is $51.24 \%$. This proportion is not significantly different from $50 \%$. Next, the proportion of firms that increased DOITAX is $28.06 \%$ and is significantly different from $50 \%$. Our interpretation of these results is that the majority of companies displayed a decrease or no change in this variable. Therefore, short-term changes for the whole sample do not support the hypothesis that liberalization increased the degree of firm internationalization. 
Test results in Table II for each industry sector for 1993-1997 are similar. They provide little support for the theoretical prediction that liberalization should increase a firm's degree of internationalization. For example, the Materials sector displayed an increase in mean (median) from $0.2553(0.2023)$ to $0.3066(0.2504)$ for DOIINC, but this increase is not statistically significant, similar to an increase in DOITAX, which is not significant either. The proportion of firms that increase DOIINC is $62.50 \%$ and insignificant, while the proportion of firms that increased DOITAX is $39.17 \%$ and significantly different from $50 \%$. Energy displayed a significant decrease in median DOIINC with the corresponding p-value of 0.0846 and the proportions of firms that increased DOIINC and DOITAX are $21.74 \%$ and $24.56 \%$, respectively. Only the Industrials sector has a significant median increase in DOITAX, but the proportion of the firms that displayed the increase is $31.58 \%$ and is significantly different from $50 \%$.

The results of tests for short-term changes are in sharp contrast with the long-term test results displayed in Table III, which shows median equality tests for the proxy variables between 1993 and 2005. Tests for the whole sample show a highly significant median increase for DOIINC, from 0.1762 to 0.4039 , with the corresponding pvalue less than 0.0001 and $72.97 \%$ of the companies displaying an increase in DOIINC. DOITAX also significantly increased in median from 0 to 0.0586 . The proportion of firms that displayed an increase in DOITAX is $48.50 \%$ and insignificant, however.

Analysis at the industry level uncovered the following. We found evidence of significant median increases in both DOIINC and DOITAX for the Materials, Health Care, Industrials, and Information Technology sectors. For example, for Industrials, DOIINC significantly increased in median by 0.1685 , with the corresponding p-value of 0.0012 for the median equality test, and $70.00 \%$ of the firms improved their DOIINC between 1993 and 2005. At the same time DOITAX increased in mean (median) by 0.1291 (0.1120), with $57.06 \%$ of firms displaying an increase in DOITAX. For Industrials, the proportion of firms that displayed an increase in both variables is statistically significant.

Several other industry sectors also displayed some evidence of an increase in the degree of internationalization. Consumer Staples and Financials significantly increased in medians for DOIINC. For example, this proxy variable changed for Consumer Staples in mean (median) from $0.3182(0.3229)$ to $0.4761(0.4777)$ and the change is significant at $10 \%$ level. In addition, the proportion of companies in this industry sector that improved their DOIINC is $85.71 \%$ and is also statistically significant. Next, Consumer Discretionary had a highly significant median increase in DOITAX, from 0 to 0.0139. Finally, Energy, Telecommunication Services, and Utilities did not display any significant changes in either of the variables, and Telecommunication Services and Utilities did not have enough usable observations to analyze median changes in DOIINC.

Overall, we find little evidence of short-term changes in the degree of internationalization. Our findings point at considerable increases in the degree of internationalization for US companies between 1993 and 2005 in the long-run, especially for industry sectors Materials, Health Care, Industrials, and Information Technology.

\section{Profitability}

A reduction in import and export duties resulting from NAFTA, in theory, should improve firm profitability. This improvement should come from cheaper foreign imports for companies that use them and have to pay import duties, and from a greater competitiveness of goods produced domestically and exported to foreign markets. We measure profitability with three proxies: return on sales (ROS), return on assets (ROA), and return on equity (ROE). In interpreting the tests for profitability changes, we follow Megginson, Nash and van Randenborgh (1994) and focus more on the ROS variable, mainly because this is a ratio of current dollar flow that is less subject to accounting adjustments than the other two ratios.

Table IV shows results of median equality tests of the profitability measures in 1993 and 1997 for the American companies. ROS has a significant positive median change from 0.0414 to 0.0451 with corresponding $\mathrm{p}$ value of 0.0049 for the median equality test. We also find that the proportion of firms that changed ROS in the predicted direction is $51.77 \%$ and significantly higher than $50 \%$, with the corresponding p-value of 0.0249 . We find similar and significant evidence for ROE. The median change in ROA is positive but lacks significance, whereas the 
proportion of the firm where ROA changed in the predicted direction is $51.83 \%$ and is significantly higher than 50\%. Therefore, we conclude that, on average, US firms significantly improved profitability during 1993-1997.

Analysis of changes in the proxies for profitability at the industry level yielded the following findings. Industry sectors Materials, Health Care, and Energy display clear signs of improvements in profitability. Materials exhibit significant median increases in ROS, ROA, and ROE and the proportions of firms where the proxy variables increased are all significantly greater than $50 \%$. Health Care has an increase in ROS statistically significant at 5\% level, while $57.60 \%$ of the firms significantly increased ROS. Median increases for all three profitability proxies for Energy are highly significant. For example, median change for ROE for the Energy sector is estimated at 0.0471, and significant with the corresponding p-value of 0.0002. Other industry sectors also exhibit some evidence of shortterm improvement. Financials have significant median increases in ROS and ROA, and Telecommunication Services display increases in ROS and ROA significant at 5\% level, and an increase in ROE with the corresponding p-value $<0.0001$. In addition, the proportion of firms, where ROS increased in the Industrials sector, is $55.65 \%$ and significant at $1 \%$ level, and increases in ROA and ROE are significant at $10 \%$ level.

The sectors that exhibited signs of profitability decrease during 1993-1997 are Consumer Discretionary, Information Technology, and Utilities. For example, medians decrease for all three profitability proxies for Utilities. The median change for ROS is -0.0126 and the null hypothesis of median equality is rejected with the corresponding p-value of 0.0130 . The proportion of firms where ROS increased is estimated at $44 \%$, but it is insignificant, and the proportion of firms where ROE increased is only $39.22 \%$ and highly significant. Consumer Discretionary displays estimated median decreases for all three profitability proxies and for ROA, this decrease is significant with p-value of 0.0095. Information Technology firms have significant decreases in means and medians for ROS and ROA, while ROE has increased in median and significant at $10 \%$ level. Hence, we have evidence that most companies display various sings of profitability increases, except Consumer Discretionary, Information Technology, and Utilities industry sectors.

Table V shows tests for long-term (1993-2005) changes in profitability proxies. Median equality tests for ROS, ROA, and ROE for the whole sample indicate highly significant profitability improvements. For example, ROS increased in mean (median) from $0.0378(0.0502)$ to $0.0632(0.0594)$ and this increase is significant with the corresponding p-value $<0.0001$. The proportion of firms where ROS increased is $57.32 \%$ and highly significant at any conventional significance level. Proportions of firms where ROA and ROE increased are insignificant, however.

We discover evidence clearly pointing at profitability improvements during 1993-2005 for industry sectors Health Care, Energy, Financials, and Industrials. In these industry sectors, both median increases and proportions of firms where profitability proxies increased are statistically significant. For instance, the proportion of firms where ROS increased is $62.56 \%$ for Health Care, $78.30 \%$ for Energy, $68.75 \%$ for Financials, and $56.93 \%$ for Industrials. In addition, for Consumer Discretionary, we estimated a mean (median) increase of 0.0091 (0.0077), the median increase is significant at 5\% level. Materials significantly increased ROE in mean (median) by 0.0530 (0.0313), and Telecommunication Services had a significant ROE increase in mean (median) by $0.2026(0.1132)$.

Finally, we found a highly significant decrease in profitability for Utilities. For this sector, we estimated decreases in means and medians of ROS, ROA, and ROE that are all significant with the corresponding p-values < 0.0001. The proportions of firms where ROS, ROA, and ROE increased are $21.74 \%, 27.66 \%$, and $33.33 \%$, respectively. In all cases, these proportions are once again highly significant. In addition, Information Technology firms display a median decrease in ROA, from 0.0520 to 0.0370 , significant at $5 \%$ level.

\section{Employment}

Table VI presents results of median equality tests of Employment between 1993 and 1997. The test result for the whole sample indicates that the number of employees in the companies in our sample significantly increased. We document mean (median) increase by 0.4968 (0.0980) thousand, the Wilcoxon/Mann-Whitney test statistic is 4.5578 and significant, with p-value $<0.0001$. Next, we discover that the proportion of firms in the whole sample, where employment decreased as predicted, is estimated at 0.2554 and statistically significant. At the industry level, we estimate significant increases in Employees medians for Consumer Discretionary, Health Care, Industrials, and 
Information Technology. For example, in Consumer Discretionary sector, the median Employees increased from 1.1190 thousand to 1.5175 , and the increase is statistically significant with the corresponding $\mathrm{p}$-value of 0.0006 for the median equality test statistic. We estimate significant decrease in median Employees for Utilities. In general, in all sectors, except Utilities, the proportion of firms where employment decreased is estimated below 50\%, the opposite from predicted. This proportion is statistically significant for all sectors except Telecommunication services. For example, the proportion of firms where Employment decreased for Information Technology is $27.86 \%$ and highly significant. In our sample, Utilities is the only sector that displays a significant decrease in Employees.

We present test results for long-term employment changes in Table VII. Tests for the whole sample indicate statistically significant employment increase in median Employees by 0.1780 thousand, with the corresponding p-value of 0.0003. Sectors Health Care, Energy, and Financials display significant median increases in Employees between 1993 and 2005, and Telecommunication Services sector displays a significant median decrease. Next, the proportion of firms where employment decreased is quite low in most industry sectors. It is estimated at $28.80 \%$ for the whole sample, and in industry sectors Consumer Discretionary, Consumer Staples, Health Care, Energy, Financials, Industrials, and Information Technology, it is significantly less than 50\%. Therefore, both short-term and long-term test results for the most firms in our sample suggest that employment increased, which is the opposite of the predicted result, except for firms in Utilities that significantly decreased their workforce during the period in question.

Tobin's $Q$

We study how the liberalization process in North America affects company values. We measure company value with Tobin's Q specified as follows: Tobin's Q1 $=($ Book Value of Total Assets - Book Value of Shareholders Equity + Market value of equity)/ Book Value of Total Assets. Test results for short-term changes in firm valuations presented in Table VI for the whole sample are inconclusive. At the industry level, we find significant median Tobin's Q increases during 1993-1997 for Energy, Financials, and Utilities, as well as significant decreases for Consumer Discretionary and Health Care. For example, in the Energy sector, Tobin's Q increased in mean (median) by $0.3660(0.2945)$ and the change is significant at any conventional level. Next, the proportion of firms where Tobin's Q increased is estimated at 56.94\% and significant for the whole sample. It is significantly greater than 50\% for sectors Energy, Financials, and Utilities, and significantly less than $50 \%$ for sectors Materials and Consumer Discretionary.

Test results for long-term changes are presented in Table VII. Similarly to the short-term test results, we find that the median equality tests between Tobin's Q in 1993 and 2005 are inconclusive, and results are sectorspecific at the industry level. Tobin's Q medians display significant increases for sectors Energy and Financials, and significant decreases for sectors Consumer Discretionary and Health Care. In addition, the proportion of firms where Tobin's Q increased between 1993 and 2005 is 52.72\% and significant for the whole sample. For industry sectors Energy and Financials it is significantly greater than 50\%. On the other hand, for sectors Consumer Discretionary and Information Technology the proportion of firms where Tobin's Q increased is significantly smaller than 50\%. Therefore, we generally find that firm valuations increased over the years; however; the effects are industry-specific and in several industry sectors, we document that Tobin's Q significantly decreased.

\section{Regression-based Test Results}

In the second part of the paper, we test our hypotheses using regression analysis. Table VIII presents estimation results and tests. A reduction in transaction controls resulting from various trade agreements that took place around 1990s, in theory, should improve firm profitability and increase the degree of internationalization and market valuation. It is common fear that liberalization will hurt workers because some firms may not be able to withstand global competition.

First, consider profitability proxies. Estimated mean ROA, ROE, and ROS values are presented in Table VIII. Mean ROA significantly increased in four industry sectors (Consumer Discretionary, Health Care, Energy, and Telecommunication Services) and significantly decreased in four sectors (Materials, Consumer Staples, Financials, and Utilities). For example, pre-1994 mean ROA is 0.0514 for the Energy sector and the value for the 
post-1994 sub-period is estimated at 0.0586 , and the null hypothesis of equality across the sub period is strongly rejected, with the corresponding Chi Square statistic of 32.8446 and significant at $1 \%$ level. ROE significantly increased in the Energy sector, and decreased in five sectors (Consumer Staples, Health Care, Financials, Information Technology, and Utilities). ROS significantly increased in seven industry sectors (Consumer Discretionary, Consumer Staples, Health Care, Energy, Financials, Industrials, and Information Technology) and decreased in one sector (Utilities). Thus, we obtain mixed evidence with respect to changes in profitability for various industry sectors in the US economy, but it is clear that Consumer Discretionary, Energy, Industrials, and Telecommunication Services increased in profitability, and Materials and Utilities decreased in profitability. We make this conclusion based on the fact that in these sectors, at least two out of three proxy variables significantly changed in a certain direction and no variable displayed a significant change in the opposite direction.

Next, results presented in Table VIII confirm that the degree of internationalization indeed increased in most cases, as expected. For all industry sectors, except Utilities, we document increases in variable DOIINC and in eight industry sectors (Materials, Consumer Discretionary, Consumer Staples, Health Care, Energy, Industrials, Information Technology, and Telecommunication Services), the increases are statistically significant. For example, mean DOIINC for the Industrials sector is 0.2535 in the pre-1994 and 0.2947 in the post-1994 sub-period, and this increase is statistically significant at $1 \%$ level with the corresponding Chi Square statistics of 25.2680. Results for the second internationalization proxy, DOITAX, are similar; i.e., all industries display mean increases in this variable and in the same eight industry sectors, increases in DOITAX are statistically significant. Therefore, evidence clearly points: that once cross-border transaction controls are reduced, firms will take advantage of new international opportunities and the degree of their international activities will increase.

Whether or not liberalization hurts workers is an important consideration. We document in Table VIII increases in the average number of employees for eight industry sectors (Materials, Consumer Discretionary, Health Care, Energy, Industrials, Information Technology, Telecommunication Services, and Utilities), and decreases in two industry sectors (Consumer Staples, and Financials). However, changes in only three sectors are statistically significant: Consumer Discretionary, Health Care, and Industrials display significant increases in the average number of employees. For example, pre-1994 mean for Industrials is 8.5376, post-1994 mean is 10.8252 thousand workers, and the null hypothesis of mean equality is rejected at $1 \%$ level. Thus, we find evidence of the increase in the average number of employees per firm in our sample, opposite from what is predicted by opponents of liberalization.

Finally, consider estimation results for Tobin's Q ratios. We estimate increases in mean values for all industry sectors, and in six sectors (Consumer Discretionary, Health Care, Energy, Industrials, Information Technology, and Telecommunication Services), the increases are statistically significant. For instance, average Tobin's Q for Telecommunication Services is 1.2862 for pre-1994 sub-sample, it is estimated at 1.7808 for the post1994 sub sample, and the change is significant at $1 \%$ level. Thus, we find significant evidence of increases in market valuation that took places along side with the liberalization process.

\section{Multivariate Analysis}

Estimation results for equations (2) and (3) are presented in Table IX. Panel A of Table IX shows that firms in our sample increase their degree of internationalization after NAFTA; for example, DOIINC increased by an estimated 0.0216, with the corresponding p-value of 0.069. DOIINC significantly increased for Health Care, Industrials, and Telecoms. Table IX Panel B presents results for firm profitability. We find no significant evidence of changes in profitability after controlling for firm and economic characteristics. Industry-level evidence shows improvements in ROA for Telecoms and decrease in ROE for Financials.

Panel C of Table IX presents test results for employment and market valuations. The evidence suggests that Employment did not change, on average; the effect is estimated by coefficient for NAFTA, which equals -0.4688 and insignificant. Industry evidence is mixed. We find that some sectors did not change employment, while the Materials, Consumer Discretionary, Health Care, Energy, Information Technology, and Utilities sectors decreased the number of employees. For example, the coefficient for NAFTA*MATERIALS is estimated -1.6475 with the corresponding $\mathrm{p}$-value of 0.037 . We also find that Tobin's $\mathrm{Q}$ decreased (the coefficient is -0.1257 and significant at 
$10 \%$ level) on average, several industry sectors decreased Tobin's Q and the Information Technology sector significantly increased Tobin's Q.

Estimation results for equation (4) are presented in Table X. The coefficients for NAFTA are positive and significant for both DOIINC and DOITAX. For example, the coefficient for NAFTA in the regression for DOIINC is 0.0456 with p-value of 0.010 . Next, the results indicate that we NAFTA*SIZE negative and significant for DOITAX; in particular, the coefficient for NAFTA*SIZE (-1) in the regression for DOITAX -0.011 with the corresponding $\mathrm{p}$-value $<0.001$. Hence, it appears that larger firms decrease their degree of internationalization after implementation of the trade agreement. The coefficient for NAFTA*LEVERAGE (-1) is positive and significant for DOITAX and proxy, NAFTA*SDS (variability of earnings) is negative and significant for both DOIINC and DOITAX.

Tests for profitability measures ROA and ROE show that none of the firm specific variables * NAFTA are significant. On the other hand, test results for Employees show the coefficient for SIZE * NAFTA is positive and significant, and it is estimated at 1.1793 and significant at any conventional level. This implies that larger firms, on average, increased employment. Finally, estimation of equation (4) for Tobin's Q reveals that the coefficient for NAFTA*SIZE is negative and significant, NAFTA* LEVERAGE is positive and significant, and NAFTA*SDS is insignificant. For example, the coefficient for NAFTA*LEVERAGE is 2.5577 and highly significant.

Overall, we find a great degree of cross-sectional differences in response of US companies to the North American Free Trade Agreement. We discover that, on average, firms increase their degree of internationalization with NAFTA, display no changes in profitability, and reduce the number of employees and market valuation. However, larger firms decrease their degree of internationalization, increase the number of employees, and further reduce market valuation, ceteris paribus. More levered firms increase their degree of internationalization and increase the number of employees and market valuation after controlling for the other factors. Finally, volatility of earnings is a factor that decreases the degree of internationalization.

\section{CONCLUSION}

This paper examines the effect of North American liberalization on the degree of internationalization and profitability of US companies using industry-level data.

We find little evidence of increases in the degree of internationalization during 1993-1997 for the whole sample and for each industry sector. We also discover that US companies, during the same time period, improved profitability, especially companies in the Materials, Health Care, and Energy sectors. We find some evidence of profitability improvements in Financials, Telecommunication Services, and Industrials. No industry displays a significant decrease in the degree of internationalization during 1993-1997. At the same time, the Consumer Discretionary, Information Technology, and Utilities sectors exhibit decreases in profitability.

We find significant long-term changes in the degree of internationalization and profitability following implementation of NAFTA. Empirical results for the whole sample and for industry sectors (Materials, Health Care, Industrials, and Information Technology) strongly indicate increases in the degree of internationalization during 1993-2005. We also find some evidence of this increase for Consumer Staples, Financials and Consumer Discretionary. Profitability during the same period clearly improved for the whole sample and for industry sectors Health Care, Energy, Financials, and Industrials. The Consumer Discretionary, Materials, and Telecommunication Services sectors also show signs of profitability improvements. We find evidence strongly pointing at the decrease in profitability for Utilities and some evidence of decreases in profitability in the Information Technology sector.

Results of multivariate analysis show that the degree of internationalization increased with NAFTA. Furthermore, we discover a lot of cross-sectional variation in firm performance following the implementation of the free trade agreement. Factors such as industry sector, firm size, leverage, and earnings variability, had a significant impact on firm performance after the introduction of NAFTA. 
Overall, our results indicate that the process of liberalization has had a positive impact on both the degree of internationalization and on firm valuation for US companies, and there is no significant evidence to support the claim that liberalization had a negative impact on workers.

\section{AUTHOR INFORMATION}

Ayşe Yüce is a professor of Finance at the Ted Rogers School of Management. She has various papers and books on investments and on international finance. Her research interests are relationships between stock exchanges, returns on foreign direct investment and multinational company efficiency and profitability.

Sergiy Rakhmayil is an Associate Professor at Ted Rogers School of Management, Ryerson University. He holds his Ph.D. in Finance from the University of Manitoba. Sergiy Rakhmayil's teaching experience is in corporate finance, international finance, and personal financial planning. His research is in corporate finance, international finance, and financial equity markets.

\section{REFERENCES}

1. Aggarwal, R., Moore, S., Long, M., Ervin, D., Industry Differences in NAFTA's Impact on the Valuation of U.S. Companies, International Review of Financial Analysis Volume: 7, Issue: 2, 1998, pp. 137-152

2. Atteberry, William L.; Swanson, Peggy E., "Equity Market Integration: The Case of North America", North American Journal of Economics and Finance Volume: 8, Issue: 1, 1997, pp. 23-37

3. Baggs, J., Brander, J., Trade liberalization, profitability, and financial leverage, Journal of International Business Studies, 2006, 37, 196-211

4. Boubakri, Narjess, and Jean-Claude Cosset, The Financial and Operating Performance of Newly Privatized Firms: Evidence from Developing Countries. Journal of Finance 53 (1998), 1081-1110.

5. Braun, G.P and Traichal, P.A., "Competitiveness and the Convergence of International Business Practice: North American Evidence after NAFTA", Global Finance Journal 10:1 (1999) 107-122

6. Chen, C., A.Cheng, J. He, J. Kim, 1997, “An Investigation of the Relationship between International Activities and Capital Structure", Journal of International Business Studies 28-3, 563-577

7. Ghani, W., I. and Haverty, J. L., "The Impact of the North American Free Trade Agreement on Multinational Firms: Evidence from the Stock Market.” Journal of International Accounting, Auditing and Taxation, Volume: 4, Issue: 2, 1995, pp. 163-173

8. Globerman, S., \& Shapiro, D., "The impact of government policies on foreign direct investment: The Canadian experience", Journal of International Business Studies, 30(3), 1999, pp 513-532.

9. Grabowski, R., and, M.S. Shields,: Development Economics, Blackwell Publishers, 1996, Cambridge, Massachusetts

10. Hejazi, W. and E. Santor, 2005, "Degree of Internationalization and Performance: An Analysis of Canadian Banks", Bank of Canada Working Paper 2005-32, 1-33

11. Hanson, R.C. and M.H. Song, "Shareholder Wealth Effects of Free Trade: U.S. and Mexican Stock Market Response to Nafta", International Review of Economics and Finance Volume: 7, Issue: 2, 1998, 209-224

12. Hodrick, R. J., and E. C. Prescott, 1997, "Postwar U.S. Business Cycles: An Empirical Investigation", Journal of Money, Credit, and Banking, 29, 1-16.

13. MacDermott, R., "Regional trade agreement and foreign direct investment", North American Journal of Economics and Finance Volume: 18, Issue: 1, February 1, 2007, pp. 107-116

14. Megginson, W. L., Nash, R., and M. van Randenborgh (1994), "The Financial and Operating Performance of Newly Privatized Firms: An International Empirical Analysis", Journal of Finance 49, 403-452.

15. Ng, A., Yuce, A., and Chen, E, "State Equity Ownership and Firm Performance: China's Newly Privatized Firms", Academy of International Business 2006 Conference Proceedings, Beijing, China, 90

16. Obstfeld, M., "Risk-taking, global diversification, and growth, American Economic Review 84, 1994, pp13101329

17. Phengpis, C., and Swanson, P. E., "Portfolio Diversification Effects of Trading Blocs: The Case of NAFTA", Journal of Multinational Financial Management Volume: 16, Issue: 3, July, 2006, pp. 315-331

18. Rodriguez, P., "Investor Expectations and the North American Free Trade Agreement", Review of International Economics, Feb2003, Vol. 11 Issue 1, p206-218, 13p

19. Thompson, A.J., "Trade liberalization, comparative advantage, and scale economies Stock market evidence from Canada", Journal of International Economics 37 (1994) 1-27 
Table I: Summary of Testable Implications

This table presents firm characteristics that we expect to change as a result of the liberalization process in North America, and empirical proxy variables used to measure these characteristics. We also outline the predicted changes in the firm performance characteristics based on economic theory. Subscriptions A and B denote firm characteristics after and before, respectively.

\begin{tabular}{|c|c|c|}
\hline Characteristics & Measure & Predicted relationship \\
\hline \multirow[t]{2}{*}{ Profitability } & Return on assets $(\mathrm{ROA})=$ Net Income $/$ Total Assets & $\mathrm{ROA}_{\mathrm{A}}>\mathrm{ROA}_{\mathrm{B}}$ \\
\hline & Return on equity $(\mathrm{ROE})=$ Net Income/Shareholders Equity & $\mathrm{ROE}_{\mathrm{A}}>\mathrm{ROE}_{\mathrm{B}}$ \\
\hline \multirow[t]{2}{*}{ Internationalization } & $\begin{array}{l}\text { Degree of internationalization based on pretax income }(\text { DOIINC) }= \\
\text { Foreign Pretax Income / (Foreign Pretax Income }+ \text { Domestic Pretax } \\
\text { Income) }\end{array}$ & DOIINC $_{A}>$ DOIINC $_{B}$ \\
\hline & $\begin{array}{l}\text { Degree of internationalization based on tax paid (DOITAX) = Foreign } \\
\text { Income Taxes / (Foreign Income Taxes }+ \text { Federal Income Taxes) }\end{array}$ & DOITAX $_{A}>$ DOITAX $_{B}$ \\
\hline Employment & Employees $=$ Total number of employees & Employees $_{\mathrm{A}}<$ Employees $_{\mathrm{B}}$ \\
\hline Company valuation & $\begin{array}{l}\text { Tobin's } Q=(\text { Total Assets }- \text { Shareholders Equity + Market value of } \\
\text { equity }) / \text { Total assets }\end{array}$ & $\mathrm{Q}_{\mathrm{A}}>\mathrm{Q}_{\mathrm{B}}$ \\
\hline
\end{tabular}

Table II: Change in the Estimated Degree of Internationalization (1993-1997)

This table presents empirical results for analysis of changes in the degree of internationalization for firms in the USA between 1993 and 1997 . It displays the number of usable observations for each proxy variable, mean (median) before, after 1994, and change in the mean (median) between 1993 and 1997. It also presents the results of Wilcoxon/ Mann-Whitney median equality test between the proxies before and after 1994 (p-values in parentheses). Finally, it displays proportion of firms that display an increase in the degree of internationalization proxies, and the test of significance of this proportion (p-values in parentheses).

\begin{tabular}{|c|c|c|c|c|c|c|c|}
\hline Variable & Obs. & $\begin{array}{l}\text { Mean } \\
\text { (Median) } \\
\text { Before } \\
\end{array}$ & $\begin{array}{l}\text { Mean } \\
\text { (Median) } \\
\text { After }\end{array}$ & $\begin{array}{l}\text { Mean } \\
\text { (Median) } \\
\text { Change } \\
\end{array}$ & $\begin{array}{l}\text { Wilcoxon/ } \\
\text { Mann- } \\
\text { Whitney } \\
\text { median } \\
\text { equality test } \\
\text { (p-value) }\end{array}$ & $\begin{array}{l}\text { Percentage of } \\
\text { firms that } \\
\text { changed as } \\
\text { predicted }\end{array}$ & $\begin{array}{l}\text { Sign (exact } \\
\text { binomial) } \\
\text { proportion } \\
\text { test that } p=0.5 \\
\text { (p-value) }\end{array}$ \\
\hline \multicolumn{8}{|c|}{ All companies } \\
\hline DOIINC & 402 & $\begin{array}{l}0.2636 \\
(0.1956)\end{array}$ & $\begin{array}{l}0.2869 \\
(0.2241)\end{array}$ & $\begin{array}{l}0.0233 \\
(0.0285)\end{array}$ & $\begin{array}{l}1.4701 \\
(0.1415)\end{array}$ & $51.24 \%$ & $\begin{array}{l}206 \\
(0.6536)\end{array}$ \\
\hline DOITAX & 1575 & $\begin{array}{l}0.1323 \\
(0.0000)\end{array}$ & $\begin{array}{l}0.1460 \\
(0.0000)\end{array}$ & $\begin{array}{l}0.0137 \\
(0.0000)\end{array}$ & $\begin{array}{l}3.0557^{\text {**** }} \\
(0.0022)\end{array}$ & $28.06 \%$ & $\begin{array}{l}1133^{* * *} \\
(0.0000)\end{array}$ \\
\hline \multicolumn{8}{|l|}{ Materials } \\
\hline DOIINC & 48 & $\begin{array}{l}0.2553 \\
(0.2023)\end{array}$ & $\begin{array}{l}0.3066 \\
(0.2504)\end{array}$ & $\begin{array}{l}0.0513 \\
(0.0481)\end{array}$ & $\begin{array}{l}1.1944 \\
(0.2323)\end{array}$ & $62.50 \%$ & $\begin{array}{l}30 \\
(0.1114)\end{array}$ \\
\hline DOITAX & 120 & $\begin{array}{l}0.1947 \\
(0.0325)\end{array}$ & $\begin{array}{l}0.1971 \\
(0.0818)\end{array}$ & $\begin{array}{l}0.0024 \\
(0.0493)\end{array}$ & $\begin{array}{l}0.5076 \\
(0.6117)\end{array}$ & $39.17 \%$ & $\begin{array}{l}73^{* *} \\
(0.0221)\end{array}$ \\
\hline \multicolumn{8}{|c|}{ Consumer Discretionary } \\
\hline DOIINC & 86 & $\begin{array}{l}0.2431 \\
(0.1656)\end{array}$ & $\begin{array}{l}0.2519 \\
(0.1642)\end{array}$ & $\begin{array}{l}0.0088 \\
(-0.0013)\end{array}$ & $\begin{array}{l}0.0750 \\
(0.9402)\end{array}$ & $46.51 \%$ & $\begin{array}{l}46 \\
(0.5900)\end{array}$ \\
\hline DOITAX & 437 & $\begin{array}{l}0.0821 \\
(0.0000)\end{array}$ & $\begin{array}{l}0.0987 \\
(0.0000)\end{array}$ & $\begin{array}{l}0.0166 \\
(0.0000)\end{array}$ & $\begin{array}{l}1.5874 \\
(0.1124)\end{array}$ & $24.03 \%$ & $\begin{array}{l}332^{* * *} \\
(0.0000)\end{array}$ \\
\hline \multicolumn{8}{|c|}{ Consumer Staples } \\
\hline DOIINC & 23 & $\begin{array}{l}0.3401 \\
(0.3259)\end{array}$ & $\begin{array}{l}0.4062 \\
(0.3843)\end{array}$ & $\begin{array}{l}0.0662 \\
(0.0584)\end{array}$ & $\begin{array}{l}0.8568 \\
(0.3916)\end{array}$ & $65.22 \%$ & $\begin{array}{l}15 \\
(0.2100)\end{array}$ \\
\hline DOITAX & 87 & $\begin{array}{l}0.1374 \\
(0.0000)\end{array}$ & $\begin{array}{l}0.1339 \\
(0.0000)\end{array}$ & $\begin{array}{l}-0.0035 \\
(0.0000)\end{array}$ & $\begin{array}{l}0.2814 \\
(0.7784)\end{array}$ & $21.84 \%$ & $\begin{array}{l}68^{* * * *} \\
(0.0000)\end{array}$ \\
\hline \multicolumn{8}{|c|}{ Health Care } \\
\hline DOIINC & 30 & $\begin{array}{l}0.3197 \\
(0.2514)\end{array}$ & $\begin{array}{l}0.3002 \\
(0.2684)\end{array}$ & $\begin{array}{l}-0.0195 \\
(0.0170)\end{array}$ & $\begin{array}{l}0.0074 \\
(0.9941)\end{array}$ & $50.00 \%$ & $\begin{array}{l}15 \\
(1.0000)\end{array}$ \\
\hline DOITAX & 131 & $\begin{array}{l}0.1346 \\
(0.0000)\end{array}$ & $\begin{array}{l}0.1788 \\
(0.0013)\end{array}$ & $\begin{array}{l}0.0442 \\
(0.0013)\end{array}$ & $\begin{array}{l}1.3754 \\
(0.1690)\end{array}$ & $29.77 \%$ & $\begin{array}{l}92^{\text {**** }} \\
(0.0000)\end{array}$ \\
\hline DOITAX & 57 & $\begin{array}{l}0.2727 \\
(0.0042)\end{array}$ & $\begin{array}{l}0.2361 \\
(0.0027)\end{array}$ & $\begin{array}{l}-0.0366 \\
(-0.0015)\end{array}$ & $\begin{array}{l}0.3032 \\
(0.7617)\end{array}$ & $24.56 \%$ & $\begin{array}{l}43^{\text {**** }} \\
(0.0002)\end{array}$ \\
\hline
\end{tabular}


Table II: continued

\begin{tabular}{|c|c|c|c|c|c|c|c|}
\hline Variable & Obs. & $\begin{array}{l}\text { Mean } \\
\text { (Median) } \\
\text { Before }\end{array}$ & $\begin{array}{l}\text { Mean } \\
\text { (Median) } \\
\text { After }\end{array}$ & $\begin{array}{l}\text { Mean } \\
\text { (Median) } \\
\text { Change }\end{array}$ & $\begin{array}{l}\text { Wilcoxon/ } \\
\text { Mann- } \\
\text { Whitney } \\
\text { median } \\
\text { equality test } \\
\text { (p-value) }\end{array}$ & $\begin{array}{l}\text { Percentage of } \\
\text { firms that } \\
\text { changed as } \\
\text { predicted }\end{array}$ & $\begin{array}{l}\text { Sign (exact } \\
\text { binomial) } \\
\text { proportion } \\
\text { test that } p=0.5 \\
\text { (p-value) }\end{array}$ \\
\hline \multicolumn{8}{|l|}{ Financials } \\
\hline DOIINC & 18 & $\begin{array}{l}0.2113 \\
(0.1292)\end{array}$ & $\begin{array}{l}0.1792 \\
(0.1740)\end{array}$ & $\begin{array}{l}-0.0321 \\
(0.0448)\end{array}$ & $\begin{array}{l}0.1740 \\
(0.8619)\end{array}$ & $33.33 \%$ & $\begin{array}{l}12 \\
(0.2379)\end{array}$ \\
\hline DOITAX & 114 & $\begin{array}{l}0.0295 \\
(0.0000)\end{array}$ & $\begin{array}{l}0.0391 \\
(0.0000)\end{array}$ & $\begin{array}{l}0.0096 \\
(0.0000)\end{array}$ & $\begin{array}{l}0.4026 \\
(0.6872)\end{array}$ & $13.16 \%$ & $\begin{array}{l}99^{\text {**** }} \\
(0.0000)\end{array}$ \\
\hline \multicolumn{8}{|c|}{ Industrials } \\
\hline DOIINC & 99 & $\begin{array}{l}0.2169 \\
(0.1528)\end{array}$ & $\begin{array}{l}0.2565 \\
(0.1819)\end{array}$ & $\begin{array}{l}0.0396 \\
(0.0291)\end{array}$ & $\begin{array}{l}1.1472 \\
(0.2513)\end{array}$ & $55.56 \%$ & $\begin{array}{l}55 \\
(0.3149)\end{array}$ \\
\hline DOITAX & 323 & $\begin{array}{l}0.1330 \\
(0.0000)\end{array}$ & $\begin{array}{l}0.1554 \\
(0.0127)\end{array}$ & $\begin{array}{l}0.0224 \\
(0.0127)\end{array}$ & $\begin{array}{l}1.8837^{*} \\
(0.0596)\end{array}$ & $31.58 \%$ & $\begin{array}{l}221^{\text {*** }} \\
(0.0000)\end{array}$ \\
\hline \multicolumn{8}{|c|}{ Information Technology } \\
\hline DOIINC & 72 & $\begin{array}{l}0.2705 \\
(0.2244)\end{array}$ & $\begin{array}{l}0.3278 \\
(0.2680)\end{array}$ & $\begin{array}{l}0.0572 \\
(0.0436)\end{array}$ & $\begin{array}{l}1.5323 \\
(0.1255)\end{array}$ & $55.56 \%$ & $\begin{array}{l}40 \\
(0.4096)\end{array}$ \\
\hline DOITAX & 236 & $\begin{array}{l}0.2396 \\
(0.0462)\end{array}$ & $\begin{array}{l}0.2472 \\
(0.1249)\end{array}$ & $\begin{array}{l}0.0076 \\
(0.0787)\end{array}$ & $\begin{array}{l}1.4308 \\
(0.1525)\end{array}$ & $40.25 \%$ & $\begin{array}{l}141^{\text {***k }} \\
(0.0033)\end{array}$ \\
\hline \multicolumn{8}{|c|}{ Telecommunication Services } \\
\hline DOIINC & 1 & $\begin{array}{l}0.3569 \\
(0.3569)\end{array}$ & $\begin{array}{l}0.1580 \\
(0.1580)\end{array}$ & $\begin{array}{l}-0.1989 \\
(-0.1989)\end{array}$ & $\begin{array}{l}0.0000 \\
(1.0000)\end{array}$ & $0.00 \%$ & $\begin{array}{l}1 \\
(1.0000)\end{array}$ \\
\hline DOITAX & 46 & $\begin{array}{l}0.0066 \\
(0.0000)\end{array}$ & $\begin{array}{l}0.0091 \\
(0.0000)\end{array}$ & $\begin{array}{l}0.0025 \\
(0.0000)\end{array}$ & $\begin{array}{l}0.1679 \\
(0.8667)\end{array}$ & $4.35 \%$ & $\begin{array}{l}44^{* * * *} \\
(0.0000)\end{array}$ \\
\hline \multicolumn{8}{|l|}{ Utilities } \\
\hline DOIINC & 2 & $\begin{array}{l}0.0761 \\
(0.0761)\end{array}$ & $\begin{array}{l}0.0748 \\
(0.0748)\end{array}$ & $\begin{array}{l}-0.0013 \\
(-0.0013)\end{array}$ & $\begin{array}{l}0.0000 \\
(1.0000)\end{array}$ & $0.00 \%$ & $\begin{array}{l}2 \\
(0.5000)\end{array}$ \\
\hline DOITAX & 24 & $\begin{array}{l}0.0347 \\
(0.0000)\end{array}$ & $\begin{array}{l}0.0511 \\
(0.0000)\end{array}$ & $\begin{array}{l}0.0165 \\
(0.0000)\end{array}$ & $\begin{array}{l}0.7114 \\
(0.4769)\end{array}$ & $16.67 \%$ & $\begin{array}{l}20^{* * * * *} \\
(0.0015)\end{array}$ \\
\hline
\end{tabular}

Table III: Change in the Estimated Degree of Internationalization (1993-2005)

This table presents empirical results for analysis of changes in the degree of internationalization for firms in the USA between 1993 and 2005 . It displays the number of usable observations for each proxy variable, mean (median) before, after 1994, and change in the mean (median) between 1993 and 2005. It also presents the results of Wilcoxon/Mann-Whitney median equality test between the proxies before and after 1994 (p-values in parentheses). Finally, it displays proportion of firms that display an increase in the degree of internationalization proxies, and the test of significance of this proportion (p-values in parentheses).

\begin{tabular}{|c|c|c|c|c|c|c|c|}
\hline Variable & Obs. & $\begin{array}{l}\text { Mean } \\
\text { (Median) } \\
\text { Before }\end{array}$ & $\begin{array}{l}\text { Mean } \\
\text { (Median) } \\
\text { After }\end{array}$ & $\begin{array}{l}\text { Mean } \\
\text { (Median) } \\
\text { Change }\end{array}$ & $\begin{array}{l}\text { Wilcoxon/ } \\
\text { Mann- } \\
\text { Whitney } \\
\text { median } \\
\text { equality test } \\
\text { (p-value) }\end{array}$ & $\begin{array}{l}\text { Percentage of } \\
\text { firms that } \\
\text { changed as } \\
\text { predicted }\end{array}$ & $\begin{array}{l}\text { Sign (exact } \\
\text { binomial) } \\
\text { proportion } \\
\text { test that } p=0.5 \\
\text { (p-value) }\end{array}$ \\
\hline \multicolumn{8}{|c|}{ All companies } \\
\hline DOIINC & 222 & $\begin{array}{l}0.2443 \\
(0.1762)\end{array}$ & $\begin{array}{l}0.4153 \\
(0.4039)\end{array}$ & $\begin{array}{l}0.1710 \\
(0.2277)\end{array}$ & $\begin{array}{l}6.3855^{\text {*** }} \\
(0.0000)\end{array}$ & $72.97 \%$ & $\begin{array}{l}162^{* * *} \\
(0.0000)\end{array}$ \\
\hline DOITAX & 769 & $\begin{array}{l}0.1282 \\
(0.0000)\end{array}$ & $\begin{array}{l}0.2314 \\
(0.0586)\end{array}$ & $\begin{array}{l}0.1032 \\
(0.0586)\end{array}$ & $\begin{array}{l}7.4241^{\text {*** }} \\
(0.0000)\end{array}$ & $48.50 \%$ & $\begin{array}{l}396 \\
(0.4276)\end{array}$ \\
\hline \multicolumn{8}{|l|}{ Materials } \\
\hline DOIINC & 29 & $\begin{array}{l}0.2196 \\
(0.1559)\end{array}$ & $\begin{array}{l}0.4390 \\
(0.4523)\end{array}$ & $\begin{array}{l}0.2194 \\
(0.2964)\end{array}$ & $\begin{array}{l}3.0636^{* * *} \\
(0.0022)\end{array}$ & $79.31 \%$ & $\begin{array}{l}23^{* * * *} \\
(0.0023)\end{array}$ \\
\hline DOITAX & 58 & $\begin{array}{l}0.1825 \\
(0.0507)\end{array}$ & $\begin{array}{l}0.3475 \\
(0.3018)\end{array}$ & $\begin{array}{l}0.1649 \\
(0.2511)\end{array}$ & $\begin{array}{l}2.8216^{* * *} \\
(0.0048)\end{array}$ & $67.24 \%$ & $\begin{array}{l}39^{* *} \\
(0.0119)\end{array}$ \\
\hline \multicolumn{8}{|c|}{ Consumer Discretionary } \\
\hline DOIINC & 45 & $\begin{array}{l}0.1947 \\
(0.1396)\end{array}$ & $\begin{array}{l}0.3076 \\
(0.1983)\end{array}$ & $\begin{array}{l}0.1128 \\
(0.0586)\end{array}$ & $\begin{array}{l}1.6220 \\
(0.1048)\end{array}$ & $64.44 \%$ & $\begin{array}{l}29^{*} \\
(0.0725)\end{array}$ \\
\hline DOITAX & 225 & $\begin{array}{l}0.0792 \\
(0.0000)\end{array}$ & $\begin{array}{l}0.1674 \\
(0.0139)\end{array}$ & $\begin{array}{l}0.0883 \\
(0.0139)\end{array}$ & $\begin{array}{l}4.1019^{* * *} \\
(0.0000)\end{array}$ & $45.33 \%$ & $\begin{array}{l}123 \\
(0.1823)\end{array}$ \\
\hline
\end{tabular}


Table III: continued

\begin{tabular}{|c|c|c|c|c|c|c|c|}
\hline Variable & Obs. & $\begin{array}{l}\begin{array}{l}\text { Mean } \\
\text { (Median) } \\
\text { Before }\end{array} \\
\end{array}$ & $\begin{array}{l}\begin{array}{l}\text { Mean } \\
\text { (Median) }\end{array} \\
\text { After }\end{array}$ & $\begin{array}{l}\begin{array}{l}\text { Mean } \\
\text { (Median) } \\
\text { Change }\end{array} \\
\end{array}$ & $\begin{array}{l}\text { Wilcoxon/ } \\
\text { Mann- } \\
\text { Whitney } \\
\text { median } \\
\text { equality test } \\
\text { (p-value) } \\
\end{array}$ & $\begin{array}{l}\text { Percentage of } \\
\text { firms that } \\
\text { changed as } \\
\text { predicted }\end{array}$ & $\begin{array}{l}\text { Sign (exact } \\
\text { binomial) } \\
\text { proportion } \\
\text { test that } p=0.5 \\
\text { (p-value) }\end{array}$ \\
\hline \multicolumn{8}{|c|}{ Consumer Staples } \\
\hline DOIINC & 14 & $\begin{array}{l}0.3182 \\
(0.3229)\end{array}$ & $\begin{array}{l}0.4761 \\
(0.4777)\end{array}$ & $\begin{array}{l}0.1579 \\
(0.1548)\end{array}$ & $\begin{array}{l}1.7690^{*} \\
(0.0769)\end{array}$ & $85.71 \%$ & $\begin{array}{l}12^{*} \\
(0.0129)\end{array}$ \\
\hline DOITAX & 42 & $\begin{array}{l}0.1320 \\
(0.0000)\end{array}$ & $\begin{array}{l}0.1412 \\
(0.0130)\end{array}$ & $\begin{array}{l}0.0092 \\
(0.0130)\end{array}$ & $\begin{array}{l}0.7649 \\
(0.4443)\end{array}$ & $33.33 \%$ & $\begin{array}{l}28^{* *} \\
(0.0436)\end{array}$ \\
\hline \multicolumn{8}{|c|}{ Health Care } \\
\hline DOIINC & 19 & $\begin{array}{l}0.2549 \\
(0.2383)\end{array}$ & $\begin{array}{l}0.5296 \\
(0.5523)\end{array}$ & $\begin{array}{l}0.2747 \\
(0.3140)\end{array}$ & $\begin{array}{l}3.3282^{* * * *} \\
(0.0009)\end{array}$ & $78.95 \%$ & $\begin{array}{l}15^{* *} \\
(0.0192)\end{array}$ \\
\hline DOITAX & 71 & $\begin{array}{l}0.1217 \\
(0.0000)\end{array}$ & $\begin{array}{l}0.2421 \\
(0.0946)\end{array}$ & $\begin{array}{l}0.1203 \\
(0.0946)\end{array}$ & $\begin{array}{l}2.4480^{* *} \\
(0.0144)\end{array}$ & $52.11 \%$ & $\begin{array}{l}37 \\
(0.8126)\end{array}$ \\
\hline \multicolumn{8}{|l|}{ Energy } \\
\hline DOIINC & 12 & $\begin{array}{l}0.3971 \\
(0.3966)\end{array}$ & $\begin{array}{l}0.5175 \\
(0.5950)\end{array}$ & $\begin{array}{l}0.1204 \\
(0.1984)\end{array}$ & $\begin{array}{l}1.0681 \\
(0.2855)\end{array}$ & $75.00 \%$ & $\begin{array}{l}9 \\
(0.1460)\end{array}$ \\
\hline DOITAX & 29 & $\begin{array}{l}0.2405 \\
(0.0000)\end{array}$ & $\begin{array}{l}0.2759 \\
(0.1122)\end{array}$ & $\begin{array}{l}0.0354 \\
(0.1122)\end{array}$ & $\begin{array}{l}0.8631 \\
(0.3881)\end{array}$ & $34.48 \%$ & $\begin{array}{l}19 \\
(0.1360)\end{array}$ \\
\hline \multicolumn{8}{|l|}{ Financials } \\
\hline DOIINC & 8 & $\begin{array}{l}0.1275 \\
(0.0815)\end{array}$ & $\begin{array}{l}0.3500 \\
(0.2383)\end{array}$ & $\begin{array}{l}0.2224 \\
(0.1568)\end{array}$ & $\begin{array}{l}1.6803^{*} \\
(0.0929)\end{array}$ & $75.00 \%$ & $\begin{array}{l}6 \\
(0.2891)\end{array}$ \\
\hline DOITAX & 54 & $\begin{array}{l}0.0249 \\
(0.0000)\end{array}$ & $\begin{array}{l}0.0700 \\
(0.0000)\end{array}$ & $\begin{array}{l}0.0451 \\
(0.0000)\end{array}$ & $\begin{array}{l}1.6068 \\
(0.1081)\end{array}$ & $29.63 \%$ & $\begin{array}{l}38^{* * *} \\
(0.0038)\end{array}$ \\
\hline \multicolumn{8}{|l|}{ Industrials } \\
\hline DOIINC & 60 & $\begin{array}{l}0.2369 \\
(0.1626)\end{array}$ & $\begin{array}{l}0.4018 \\
(0.3312)\end{array}$ & $\begin{array}{l}0.1649 \\
(0.1685)\end{array}$ & $\begin{array}{l}3.2489^{* * *} \\
(0.0012)\end{array}$ & $70.00 \%$ & $\begin{array}{l}42^{* * * *} \\
(0.0027)\end{array}$ \\
\hline DOITAX & 170 & $\begin{array}{l}0.1257 \\
(0.0000)\end{array}$ & $\begin{array}{l}0.2548 \\
(0.1120)\end{array}$ & $\begin{array}{l}0.1291 \\
(0.1120)\end{array}$ & $\begin{array}{l}4.2103^{* * *} \\
(0.0000)\end{array}$ & $57.06 \%$ & $\begin{array}{l}97^{*} \\
(0.0774)\end{array}$ \\
\hline \multicolumn{8}{|c|}{ Information Technology } \\
\hline DOIINC & 34 & $\begin{array}{l}0.2887 \\
(0.2212)\end{array}$ & $\begin{array}{l}0.4643 \\
(0.4116)\end{array}$ & $\begin{array}{l}0.1756 \\
(0.1904)\end{array}$ & $\begin{array}{l}2.4224^{* *} \\
(0.0154)\end{array}$ & $76.47 \%$ & $\begin{array}{l}26^{* * *} \\
(0.0029)\end{array}$ \\
\hline DOITAX & 103 & $\begin{array}{l}0.2554 \\
(0.0877)\end{array}$ & $\begin{array}{l}0.3956 \\
(0.2667)\end{array}$ & $\begin{array}{l}0.1402 \\
(0.1790)\end{array}$ & $\begin{array}{l}3.0143^{* * *} \\
(0.0026)\end{array}$ & $53.40 \%$ & $\begin{array}{l}55 \\
(0.5546)\end{array}$ \\
\hline \multicolumn{8}{|c|}{ Telecommunication Services } \\
\hline DOIINC & 1 & $\begin{array}{l}0.0000 \\
(0.0000)\end{array}$ & $\begin{array}{l}0.0000 \\
(0.0000)\end{array}$ & $\begin{array}{l}0.0000 \\
(0.0000)\end{array}$ & $\begin{array}{l}-1.0000 \\
(0.3173)\end{array}$ & $0.00 \%$ & $\begin{array}{l}1 \\
(1.0000)\end{array}$ \\
\hline DOITAX & 8 & $\begin{array}{l}0.0000 \\
(0.0000)\end{array}$ & $\begin{array}{l}0.0069 \\
(0.0000)\end{array}$ & $\begin{array}{l}0.0069 \\
(0.0000)\end{array}$ & $\begin{array}{l}0.3676 \\
(0.7132)\end{array}$ & $12.50 \%$ & $\begin{array}{l}7 \\
(0.0703)\end{array}$ \\
\hline \multicolumn{8}{|l|}{ Utilities } \\
\hline DOIINC & 0 & $\begin{array}{l}\text { NA } \\
\text { NA }\end{array}$ & $\begin{array}{l}\mathrm{NA} \\
\mathrm{NA}\end{array}$ & $\begin{array}{l}\text { NA } \\
\text { NA }\end{array}$ & & & \\
\hline DOITAX & 9 & $\begin{array}{l}0.0000 \\
(0.0000)\end{array}$ & $\begin{array}{l}0.1238 \\
(0.0000)\end{array}$ & $\begin{array}{l}0.1238 \\
(0.0000)\end{array}$ & $\begin{array}{l}0.7506 \\
(0.4529)\end{array}$ & $22.22 \%$ & $\begin{array}{l}7 \\
(0.1797)\end{array}$ \\
\hline
\end{tabular}

*** denotes $1 \%$ significance, $* *$ denotes $5 \%$ significance, and * denotes $10 \%$ significance levels 
Table IV: Change in Profitability (1993-1997)

This table presents empirical results for analysis of profitability changes for the whole sample and industry sectors of the US firms. It displays the number of usable observations for each proxy variable, mean (median) before, after 1994, and change in the mean (median) between 1993 and 1997. It also presents the results of Wilcoxon/Mann-Whitney median equality test between the proxies before and after 1994 (p-values in parentheses). Finally, it displays proportion of firms that changed performance proxies in the predicted direction, and the test of significance of this proportion ( $\mathrm{p}$-values in parentheses).

\begin{tabular}{|c|c|c|c|c|c|c|c|}
\hline Variable & Obs. & $\begin{array}{l}\text { Mean } \\
\text { (Median) } \\
\text { Before } \\
\end{array}$ & $\begin{array}{l}\text { Mean } \\
\text { (Median) } \\
\text { After }\end{array}$ & $\begin{array}{l}\text { Mean } \\
\text { (Median) } \\
\text { Change } \\
\end{array}$ & $\begin{array}{l}\text { Wilcoxon/ } \\
\text { Mann- } \\
\text { Whitney } \\
\text { median } \\
\text { equality test } \\
\text { (p-value) } \\
\end{array}$ & $\begin{array}{l}\text { Percentage of } \\
\text { firms that } \\
\text { changed as } \\
\text { predicted }\end{array}$ & $\begin{array}{l}\text { Sign (exact } \\
\text { binomial) } \\
\text { proportion } \\
\text { test that } p=0.5 \\
\text { (p-value) }\end{array}$ \\
\hline \multicolumn{8}{|l|}{ All companies } \\
\hline ROS & 4266 & $\begin{array}{l}0.0174 \\
(0.0414)\end{array}$ & $\begin{array}{l}0.0270 \\
(0.0451)\end{array}$ & $\begin{array}{l}0.0096 \\
(0.0037)\end{array}$ & $\begin{array}{l}2.8115^{* * *} \\
(0.0049)\end{array}$ & $51.77 \%$ & $\begin{array}{l}2104^{* *} \\
(0.0249)\end{array}$ \\
\hline ROA & 4364 & $\begin{array}{l}0.0115 \\
(0.0256)\end{array}$ & $\begin{array}{l}0.0081 \\
(0.0264)\end{array}$ & $\begin{array}{l}-0.0035 \\
(0.0009)\end{array}$ & $\begin{array}{l}0.7952 \\
(0.4265)\end{array}$ & $51.83 \%$ & $\begin{array}{l}2113^{* *} \\
(0.0204)\end{array}$ \\
\hline ROE & 4353 & $\begin{array}{l}0.0422 \\
(0.0910)\end{array}$ & $\begin{array}{l}0.0498 \\
(0.1026)\end{array}$ & $\begin{array}{l}0.0076 \\
(0.0116)\end{array}$ & $\begin{array}{l}5.1548^{* * *} \\
(0.0000)\end{array}$ & $52.48 \%$ & $\begin{array}{l}2117^{* * *} \\
(0.0017)\end{array}$ \\
\hline \multicolumn{8}{|l|}{ Materials } \\
\hline ROS & 260 & $\begin{array}{l}0.0112 \\
(0.0269)\end{array}$ & $\begin{array}{l}0.0272 \\
(0.0386)\end{array}$ & $\begin{array}{l}0.0160 \\
(0.0117)\end{array}$ & $\begin{array}{l}3.2615^{* * *} \\
(0.0011)\end{array}$ & $57.55 \%$ & $\begin{array}{l}141^{* *} \\
(0.0213)\end{array}$ \\
\hline ROA & 265 & $\begin{array}{l}0.0129 \\
(0.0245)\end{array}$ & $\begin{array}{l}0.0260 \\
(0.0395)\end{array}$ & $\begin{array}{l}0.0130 \\
(0.0150)\end{array}$ & $\begin{array}{l}2.6418^{* * * *} \\
(0.0082)\end{array}$ & $55.92 \%$ & $\begin{array}{l}137^{*} \\
(0.0734)\end{array}$ \\
\hline ROE & 264 & $\begin{array}{l}0.0099 \\
(0.0622)\end{array}$ & $\begin{array}{l}0.0699 \\
(0.0986)\end{array}$ & $\begin{array}{l}0.0601 \\
(0.0364)\end{array}$ & $\begin{array}{l}3.9242^{* * *} \\
(0.0001)\end{array}$ & $58.54 \%$ & $\begin{array}{l}144^{* * * *} \\
(0.0088)\end{array}$ \\
\hline \multicolumn{8}{|c|}{ Consumer Discretionary } \\
\hline ROS & 912 & $\begin{array}{l}0.0195 \\
(0.0307)\end{array}$ & $\begin{array}{l}0.0147 \\
(0.0278)\end{array}$ & $\begin{array}{l}-0.0049 \\
(-0.0029)\end{array}$ & $\begin{array}{l}1.5718 \\
(0.1160)\end{array}$ & $46.29 \%$ & $\begin{array}{l}463^{* *} \\
(0.0318)\end{array}$ \\
\hline ROA & 930 & $\begin{array}{l}0.0298 \\
(0.0404)\end{array}$ & $\begin{array}{l}0.0149 \\
(0.0354)\end{array}$ & $\begin{array}{l}-0.0149 \\
(-0.0050)\end{array}$ & $\begin{array}{l}2.5937^{* * * *} \\
(0.0095)\end{array}$ & $46.71 \%$ & $\begin{array}{l}461^{*} \\
(0.0568)\end{array}$ \\
\hline ROE & 929 & $\begin{array}{l}0.0662 \\
(0.0988)\end{array}$ & $\begin{array}{l}0.0341 \\
(0.0933)\end{array}$ & $\begin{array}{l}-0.0321 \\
(-0.0055)\end{array}$ & $\begin{array}{l}1.5274 \\
(0.1267)\end{array}$ & $47.66 \%$ & $\begin{array}{l}447 \\
(0.1820)\end{array}$ \\
\hline \multicolumn{8}{|c|}{ Consumer Staples } \\
\hline ROS & 166 & $\begin{array}{l}0.0141 \\
(0.0263)\end{array}$ & $\begin{array}{l}0.0293 \\
(0.0323)\end{array}$ & $\begin{array}{l}0.0152 \\
(0.0060)\end{array}$ & $\begin{array}{l}1.1121 \\
(0.2661)\end{array}$ & $56.69 \%$ & $\begin{array}{l}89 \\
(0.1102)\end{array}$ \\
\hline ROA & 168 & $\begin{array}{l}0.0296 \\
(0.0421)\end{array}$ & $\begin{array}{l}0.0337 \\
(0.0481)\end{array}$ & $\begin{array}{l}0.0041 \\
(0.0060)\end{array}$ & $\begin{array}{l}0.9351 \\
(0.3497)\end{array}$ & $55.35 \%$ & $\begin{array}{l}88 \\
(0.2043)\end{array}$ \\
\hline ROE & 167 & $\begin{array}{l}0.0621 \\
(0.0888)\end{array}$ & $\begin{array}{l}0.0723 \\
(0.0976)\end{array}$ & $\begin{array}{l}0.0102 \\
(0.0087)\end{array}$ & $\begin{array}{l}1.1040 \\
(0.2696)\end{array}$ & $56.60 \%$ & $\begin{array}{l}90 \\
(0.1124)\end{array}$ \\
\hline \multicolumn{8}{|l|}{ Health Care } \\
\hline ROS & 402 & $\begin{array}{l}-1.0796 \\
(0.0028)\end{array}$ & $\begin{array}{l}-0.4402 \\
(0.0094)\end{array}$ & $\begin{array}{c}0.6394 \\
(0.0066)\end{array}$ & $\begin{array}{l}2.1562^{* *} \\
(0.0311)\end{array}$ & $57.60 \%$ & $\begin{array}{c}216^{* * *} \\
(0.0038)\end{array}$ \\
\hline ROA & 429 & $\begin{array}{l}-0.1186 \\
(-0.0177)\end{array}$ & $\begin{array}{l}-0.1265 \\
(0.0010)\end{array}$ & $\begin{array}{l}-0.0079 \\
(0.0187)\end{array}$ & $\begin{array}{c}1.0224 \\
(0.3066)\end{array}$ & $48.86 \%$ & $\begin{array}{c}202 \\
(0.6874)\end{array}$ \\
\hline ROE & 429 & $\begin{array}{c}-0.1444 \\
(-0.0094)\end{array}$ & $\begin{array}{l}-0.1695 \\
(0.0151)\end{array}$ & $\begin{array}{l}-0.0251 \\
(0.0246)\end{array}$ & $\begin{array}{c}1.3365 \\
(0.1814)\end{array}$ & $47.69 \%$ & $\begin{array}{c}204 \\
(0.3894)\end{array}$ \\
\hline \multicolumn{8}{|l|}{ Energy } \\
\hline ROS & 207 & $\begin{array}{c}0.0166 \\
(0.0367)\end{array}$ & $\begin{array}{c}0.0316 \\
(0.0635)\end{array}$ & $\begin{array}{c}0.0150 \\
(0.0268)\end{array}$ & $\begin{array}{l}2.4283^{* *} \\
(0.0152)\end{array}$ & $66.16 \%$ & $\begin{array}{c}131^{* * *} \\
(0.0000)\end{array}$ \\
\hline ROA & 209 & $\begin{array}{c}0.0219 \\
(0.0241)\end{array}$ & $\begin{array}{c}0.0316 \\
(0.0419)\end{array}$ & $\begin{array}{c}0.0098 \\
(0.0178)\end{array}$ & $\begin{array}{l}2.7219^{* * * *} \\
(0.0065)\end{array}$ & $64.65 \%$ & $\begin{array}{l}128^{* * *} \\
(0.0000)\end{array}$ \\
\hline ROE & 208 & $\begin{array}{c}0.0466 \\
(0.0569)\end{array}$ & $\begin{array}{c}0.0752 \\
(0.1040)\end{array}$ & $\begin{array}{c}0.0287 \\
(0.0471)\end{array}$ & $\begin{array}{l}3.6998^{* * *} \\
(0.0002)\end{array}$ & $66.49 \%$ & $\begin{array}{c}129^{* * * *} \\
(0.0000)\end{array}$ \\
\hline \multicolumn{8}{|l|}{ Financials } \\
\hline ROS & 827 & $\begin{array}{c}0.1138 \\
(0.1168)\end{array}$ & $\begin{array}{c}0.1274 \\
(0.1229)\end{array}$ & $\begin{array}{c}0.0135 \\
(0.0060)\end{array}$ & $\begin{array}{l}2.8497^{* * *} \\
(0.0044)\end{array}$ & $49.10 \%$ & $\begin{array}{c}396 \\
(0.6412)\end{array}$ \\
\hline ROA & 839 & $\begin{array}{c}0.0187 \\
(0.0120)\end{array}$ & $\begin{array}{c}0.0192 \\
(0.0127)\end{array}$ & $\begin{array}{c}0.0005 \\
(0.0007)\end{array}$ & $\begin{array}{l}2.2278^{* *} \\
(0.0259)\end{array}$ & $53.44 \%$ & $\begin{array}{c}420^{*} \\
(0.0586)\end{array}$ \\
\hline ROE & 837 & $\begin{array}{c}0.1065 \\
(0.1141)\end{array}$ & $\begin{array}{c}0.1146 \\
(0.1171)\end{array}$ & $\begin{array}{c}0.0081 \\
(0.0030)\end{array}$ & $\begin{array}{c}1.5847 \\
(0.1130)\end{array}$ & $52.84 \%$ & $\begin{array}{c}410 \\
(0.1226)\end{array}$ \\
\hline
\end{tabular}


Table IV: continued

\begin{tabular}{|c|c|c|c|c|c|c|c|}
\hline Variable & Obs. & $\begin{array}{l}\text { Mean } \\
\text { (Median) } \\
\text { Before }\end{array}$ & $\begin{array}{l}\text { Mean } \\
\text { (Median) } \\
\text { After }\end{array}$ & $\begin{array}{l}\text { Mean } \\
\text { (Median) } \\
\text { Change }\end{array}$ & $\begin{array}{l}\text { Wilcoxon/ } \\
\text { Mann- } \\
\text { Whitney } \\
\text { median } \\
\text { equality test } \\
\text { (p-value) }\end{array}$ & $\begin{array}{l}\text { Percentage of } \\
\text { firms that } \\
\text { changed as } \\
\text { predicted }\end{array}$ & $\begin{array}{l}\text { Sign (exact } \\
\text { binomial) } \\
\text { proportion } \\
\text { test that } p=0.5 \\
\text { (p-value) }\end{array}$ \\
\hline \multicolumn{8}{|l|}{ Industrials } \\
\hline ROS & 717 & $\begin{array}{c}0.0163 \\
(0.0303)\end{array}$ & $\begin{array}{c}0.0176 \\
(0.0352)\end{array}$ & $\begin{array}{c}0.0013 \\
(0.0049)\end{array}$ & $\begin{array}{c}1.4073 \\
(0.1593)\end{array}$ & $55.65 \%$ & $\begin{array}{c}374^{* * *} \\
(0.0038)\end{array}$ \\
\hline ROA & 729 & $\begin{array}{c}0.0199 \\
(0.0358)\end{array}$ & $\begin{array}{c}0.0199 \\
(0.0414)\end{array}$ & $\begin{array}{c}0.0000 \\
(0.0056)\end{array}$ & $\begin{array}{c}1.2327 \\
(0.2177)\end{array}$ & $53.78 \%$ & $\begin{array}{c}363^{*} \\
(0.0542)\end{array}$ \\
\hline ROE & 729 & $\begin{array}{c}0.0444 \\
(0.0821)\end{array}$ & $\begin{array}{c}0.0583 \\
(0.1034)\end{array}$ & $\begin{array}{c}0.0139 \\
(0.0213)\end{array}$ & $\begin{array}{l}2.9517^{* * * *} \\
(0.0032)\end{array}$ & $53.79 \%$ & $\begin{array}{c}362^{*} \\
(0.0539)\end{array}$ \\
\hline \multicolumn{8}{|c|}{ Information Technology } \\
\hline ROS & 538 & $\begin{array}{l}-0.0166 \\
(0.0277)\end{array}$ & $\begin{array}{l}-0.0386 \\
(0.0237)\end{array}$ & $\begin{array}{c}-0.0220 \\
(-0.0041)\end{array}$ & $\begin{array}{c}1.7583^{*} \\
(0.0787)\end{array}$ & $48.42 \%$ & $\begin{array}{c}261 \\
(0.5049)\end{array}$ \\
\hline ROE & 546 & $\begin{array}{l}-0.0125 \\
(0.0783)\end{array}$ & $\begin{array}{c}0.0011 \\
(0.0788)\end{array}$ & $\begin{array}{c}0.0137 \\
(0.0005)\end{array}$ & $\begin{array}{c}1.9399^{*} \\
(0.0524)\end{array}$ & $51.59 \%$ & $\begin{array}{c}260 \\
(0.5041)\end{array}$ \\
\hline \multicolumn{8}{|c|}{ Telecommunication Services } \\
\hline ROS & 76 & $\begin{array}{l}-0.0211 \\
(0.0356)\end{array}$ & $\begin{array}{c}-0.0205 \\
(0.0840)\end{array}$ & $\begin{array}{c}0.0007 \\
(0.0484)\end{array}$ & $\begin{array}{l}2.1575^{\text {** }} \\
(0.0310)\end{array}$ & $57.75 \%$ & $\begin{array}{c}41 \\
(0.2351)\end{array}$ \\
\hline ROA & 82 & $\begin{array}{l}-0.0092 \\
(0.0064)\end{array}$ & $\begin{array}{l}-0.0025 \\
(0.0388)\end{array}$ & $\begin{array}{c}0.0067 \\
(0.0325)\end{array}$ & $\begin{array}{l}2.1624^{* *} \\
(0.0306)\end{array}$ & $65.33 \%$ & $\begin{array}{c}49^{* *} \\
(0.0106)\end{array}$ \\
\hline ROE & 81 & $\begin{array}{l}-0.0299 \\
(0.0334)\end{array}$ & $\begin{array}{c}0.1742 \\
(0.1920)\end{array}$ & $\begin{array}{c}0.2041 \\
(0.1586)\end{array}$ & $\begin{array}{l}5.0179^{* * * *} \\
(0.0000)\end{array}$ & $71.23 \%$ & $\begin{array}{c}52^{\text {***k }} \\
(0.0004)\end{array}$ \\
\hline \multicolumn{8}{|l|}{ Utilities } \\
\hline ROS & 163 & $\begin{array}{c}0.0834 \\
(0.0859)\end{array}$ & $\begin{array}{c}0.0740 \\
(0.0734)\end{array}$ & $\begin{array}{c}-0.0094 \\
(-0.0126)\end{array}$ & $\begin{array}{l}2.4845^{\text {** }} \\
(0.0130)\end{array}$ & $44.00 \%$ & $\begin{array}{c}84 \\
(0.1649)\end{array}$ \\
\hline ROA & 163 & $\begin{array}{c}0.0353 \\
(0.0377)\end{array}$ & $\begin{array}{c}0.0337 \\
(0.0346)\end{array}$ & $\begin{array}{c}-0.0015 \\
(-0.0031)\end{array}$ & $\begin{array}{l}1.7112^{*} \\
(0.0871)\end{array}$ & $49.02 \%$ & $\begin{array}{c}78 \\
(0.8716)\end{array}$ \\
\hline
\end{tabular}

$* * *$ denotes $1 \%$ significance, $* *$ denotes $5 \%$ significance, and $*$ denotes $10 \%$ significance levels 
Table V: Change in Profitability (1993-2005)

This table presents empirical results for analysis of profitability changes for the whole sample and industry sectors of the US firms. It displays the number of usable observations for each proxy variable, mean (median) before, after 1994, and change in the mean (median) between 1993 and 2005. It also presents the results of Wilcoxon/ Mann-Whitney median equality test between the proxies before and after 1994 (p-values in parentheses). Finally, it displays proportion of firms that changed performance proxies in the predicted direction, and the test of significance of this proportion ( $\mathrm{p}$-values in parentheses).

\begin{tabular}{|c|c|c|c|c|c|c|c|}
\hline Variable & Obs. & $\begin{array}{l}\begin{array}{l}\text { Mean } \\
\text { (Median) } \\
\text { Before }\end{array} \\
\end{array}$ & $\begin{array}{l}\begin{array}{l}\text { Mean } \\
\text { (Median) }\end{array} \\
\text { After } \\
\end{array}$ & $\begin{array}{l}\begin{array}{l}\text { Mean } \\
\text { (Median) } \\
\text { Change }\end{array} \\
\end{array}$ & $\begin{array}{l}\text { Wilcoxon/ } \\
\text { Mann- } \\
\text { Whitney } \\
\text { median } \\
\text { equality test } \\
\text { (p-value) } \\
\end{array}$ & $\begin{array}{l}\text { Percentage of } \\
\text { firms that } \\
\text { changed as } \\
\text { predicted }\end{array}$ & $\begin{array}{l}\text { Sign (exact } \\
\text { binomial) } \\
\text { proportion } \\
\text { test that } p=0.5 \\
\text { (p-value) }\end{array}$ \\
\hline \multicolumn{8}{|c|}{ All companies } \\
\hline ROS & 2040 & $\begin{array}{l}0.0378 \\
(0.0502)\end{array}$ & $\begin{array}{l}0.0632 \\
(0.0594)\end{array}$ & $\begin{array}{l}0.0255 \\
(0.0092)\end{array}$ & $\begin{array}{l}5.9420^{* * * *} \\
(0.0000)\end{array}$ & $57.32 \%$ & $\begin{array}{l}1104^{* * *} \\
(0.0000)\end{array}$ \\
\hline ROA & 2084 & $\begin{array}{l}0.0250 \\
(0.0323)\end{array}$ & $\begin{array}{l}0.0327 \\
(0.0366)\end{array}$ & $\begin{array}{l}0.0076 \\
(0.0043)\end{array}$ & $\begin{array}{l}3.1368^{* * *} \\
(0.0017)\end{array}$ & $51.07 \%$ & $\begin{array}{l}982 \\
(0.3617)\end{array}$ \\
\hline ROE & 2084 & $\begin{array}{l}0.0696 \\
(0.1057)\end{array}$ & $\begin{array}{l}0.0984 \\
(0.1134)\end{array}$ & $\begin{array}{l}0.0288 \\
(0.0077)\end{array}$ & $\begin{array}{l}5.2176^{* * *} \\
(0.0000)\end{array}$ & $50.58 \%$ & $\begin{array}{l}961 \\
(0.6300)\end{array}$ \\
\hline \multicolumn{8}{|l|}{ Materials } \\
\hline ROS & 129 & $\begin{array}{l}0.0244 \\
(0.0334)\end{array}$ & $\begin{array}{l}0.0335 \\
(0.0395)\end{array}$ & $\begin{array}{l}0.0091 \\
(0.0061)\end{array}$ & $\begin{array}{l}1.4634 \\
(0.1434)\end{array}$ & $54.62 \%$ & $\begin{array}{l}65 \\
(0.3594)\end{array}$ \\
\hline ROA & 132 & $\begin{array}{l}0.0257 \\
(0.0314)\end{array}$ & $\begin{array}{l}0.0342 \\
(0.0396)\end{array}$ & $\begin{array}{l}0.0085 \\
(0.0082)\end{array}$ & $\begin{array}{l}1.2470 \\
(0.2124)\end{array}$ & $54.92 \%$ & $\begin{array}{l}67 \\
(0.3193)\end{array}$ \\
\hline ROE & 132 & $\begin{array}{l}0.0309 \\
(0.0763)\end{array}$ & $\begin{array}{l}0.0839 \\
(0.1077)\end{array}$ & $\begin{array}{l}0.0530 \\
(0.0313)\end{array}$ & $\begin{array}{l}2.9348^{* * * *} \\
(0.0033)\end{array}$ & $59.02 \%$ & $\begin{array}{l}72^{* *} \\
(0.0568)\end{array}$ \\
\hline \multicolumn{8}{|c|}{ Consumer Discretionary } \\
\hline ROS & 409 & $\begin{array}{l}0.0336 \\
(0.0360)\end{array}$ & $\begin{array}{l}0.0428 \\
(0.0436)\end{array}$ & $\begin{array}{l}0.0091 \\
(0.0077)\end{array}$ & $\begin{array}{l}2.0622^{* * *} \\
(0.0392)\end{array}$ & $53.70 \%$ & $\begin{array}{l}203 \\
(0.1648)\end{array}$ \\
\hline ROA & 418 & $\begin{array}{l}0.0458 \\
(0.0478)\end{array}$ & $\begin{array}{l}0.0492 \\
(0.0562)\end{array}$ & $\begin{array}{l}0.0034 \\
(0.0085)\end{array}$ & $\begin{array}{l}1.1548 \\
(0.2482)\end{array}$ & $50.13 \%$ & $\begin{array}{l}192 \\
(1.0000)\end{array}$ \\
\hline ROE & 419 & $\begin{array}{l}0.1030 \\
(0.1189)\end{array}$ & $\begin{array}{l}0.1044 \\
(0.1183)\end{array}$ & $\begin{array}{l}0.0014 \\
(-0.0006)\end{array}$ & $\begin{array}{l}0.4082 \\
(0.6832)\end{array}$ & $47.12 \%$ & $\begin{array}{l}202 \\
(0.2826)\end{array}$ \\
\hline \multicolumn{8}{|c|}{ Consumer Staples } \\
\hline ROS & 78 & $\begin{array}{l}0.0423 \\
(0.0425)\end{array}$ & $\begin{array}{l}0.0459 \\
(0.0430)\end{array}$ & $\begin{array}{l}0.0036 \\
(0.0005)\end{array}$ & $\begin{array}{l}0.5512 \\
(0.5815)\end{array}$ & $57.53 \%$ & $\begin{array}{l}42 \\
(0.2416)\end{array}$ \\
\hline ROA & 79 & $\begin{array}{l}0.0562 \\
(0.0556)\end{array}$ & $\begin{array}{l}0.0588 \\
(0.0634)\end{array}$ & $\begin{array}{l}0.0027 \\
(0.0077)\end{array}$ & $\begin{array}{l}0.7337 \\
(0.4631)\end{array}$ & $50.00 \%$ & $\begin{array}{l}37 \\
(1.0000)\end{array}$ \\
\hline ROE & 79 & $\begin{array}{l}0.1066 \\
(0.1179)\end{array}$ & $\begin{array}{l}0.1863 \\
(0.1289)\end{array}$ & $\begin{array}{l}0.0797 \\
(0.0110)\end{array}$ & $\begin{array}{l}1.9543^{*} \\
(0.0507)\end{array}$ & $55.41 \%$ & $\begin{array}{l}41 \\
(0.4160)\end{array}$ \\
\hline \multicolumn{8}{|c|}{ Health Care } \\
\hline ROS & 212 & $\begin{array}{l}-0.6680 \\
(0.0034)\end{array}$ & $\begin{array}{l}-0.2955 \\
(0.0401)\end{array}$ & $\begin{array}{l}0.3725 \\
(0.0367)\end{array}$ & $\begin{array}{l}3.9127^{* * *} \\
(0.0001)\end{array}$ & $62.56 \%$ & $\begin{array}{l}122^{* * *} \\
(0.0006)\end{array}$ \\
\hline ROA & 230 & $\begin{array}{l}-0.1097 \\
(-0.0129)\end{array}$ & $\begin{array}{l}-0.0650 \\
(0.0290)\end{array}$ & $\begin{array}{l}0.0448 \\
(0.0419)\end{array}$ & $\begin{array}{l}2.7887^{* * *} \\
(0.0053)\end{array}$ & $55.92 \%$ & $\begin{array}{l}118^{*} \\
(0.0983)\end{array}$ \\
\hline ROE & 230 & $\begin{array}{l}-0.1595 \\
(-0.0075)\end{array}$ & $\begin{array}{l}-0.0620 \\
(0.0741)\end{array}$ & $\begin{array}{l}0.0975 \\
(0.0815)\end{array}$ & $\begin{array}{l}3.7034^{* * *} \\
(0.0002)\end{array}$ & $56.52 \%$ & $\begin{array}{l}117^{*} \\
(0.0705)\end{array}$ \\
\hline \multicolumn{8}{|l|}{ Energy } \\
\hline ROS & 110 & $\begin{array}{l}0.1002 \\
(0.0522)\end{array}$ & $\begin{array}{l}0.2258 \\
(0.1818)\end{array}$ & $\begin{array}{l}0.1256 \\
(0.1296)\end{array}$ & $\begin{array}{l}5.7397^{* * *} \\
(0.0000)\end{array}$ & $78.30 \%$ & $\begin{array}{l}83^{* * *} \\
(0.0000)\end{array}$ \\
\hline ROA & 112 & $\begin{array}{l}0.0481 \\
(0.0377)\end{array}$ & $\begin{array}{l}0.1657 \\
(0.0974)\end{array}$ & $\begin{array}{l}0.1177 \\
(0.0598)\end{array}$ & $\begin{array}{l}7.2777^{* * *} \\
(0.0000)\end{array}$ & $80.00 \%$ & $\begin{array}{l}84^{* * * *} \\
(0.0000)\end{array}$ \\
\hline ROE & 112 & $\begin{array}{l}0.0958 \\
(0.0693)\end{array}$ & $\begin{array}{l}0.2654 \\
(0.1935)\end{array}$ & $\begin{array}{l}0.1697 \\
(0.1242)\end{array}$ & $\begin{array}{l}7.3622^{* * *} \\
(0.0000)\end{array}$ & $78.85 \%$ & $\begin{array}{l}82^{* * * *} \\
(0.0000)\end{array}$ \\
\hline \multicolumn{8}{|c|}{ Financials } \\
\hline ROS & 400 & $\begin{array}{l}0.1310 \\
(0.1278)\end{array}$ & $\begin{array}{l}0.1673 \\
(0.1607)\end{array}$ & $\begin{array}{l}0.0362 \\
(0.0329)\end{array}$ & $\begin{array}{l}6.6819^{* * *} \\
(0.0000)\end{array}$ & $68.75 \%$ & $\begin{array}{l}253^{* * *} \\
(0.0000)\end{array}$ \\
\hline ROA & 405 & $\begin{array}{l}0.0223 \\
(0.0132)\end{array}$ & $\begin{array}{l}0.0233 \\
(0.0141)\end{array}$ & $\begin{array}{l}0.0010 \\
(0.0009)\end{array}$ & $\begin{array}{l}1.2525 \\
(0.2104)\end{array}$ & $50.92 \%$ & $\begin{array}{l}193 \\
(0.7580)\end{array}$ \\
\hline ROE & 405 & $\begin{array}{l}0.1200 \\
(0.1243)\end{array}$ & $\begin{array}{l}0.1288 \\
(0.1294)\end{array}$ & $\begin{array}{l}0.0088 \\
(0.0051)\end{array}$ & $\begin{array}{l}1.7775^{*} \\
(0.0755)\end{array}$ & $47.59 \%$ & $\begin{array}{l}196 \\
(0.3794)\end{array}$ \\
\hline
\end{tabular}


Table V: continued

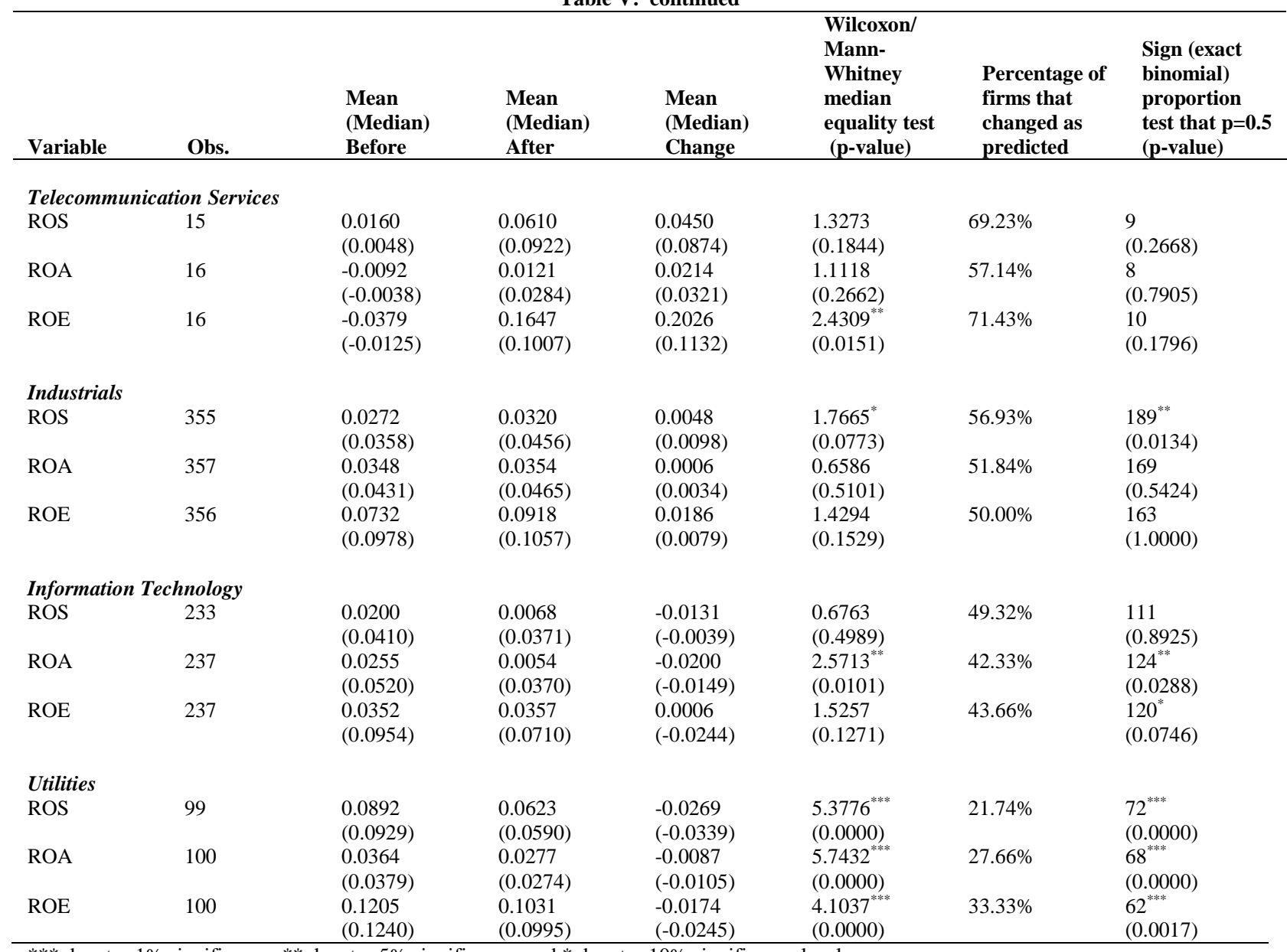

$* * *$ denotes $1 \%$ significance, $* *$ denotes $5 \%$ significance, and $*$ denotes $10 \%$ significance levels 
Table VI: Change in Firm Employment and Tobin's Q (1993-1997)

This table presents empirical results for analysis of changes in the number of employees, as well as changes in firm valuation as measured by Tobin's Q ratio for firms in the USA between 1993 and 1997. It displays the number of usable observations for each proxy variable, mean (median) before, after 1994, and change in the mean (median) between 1993 and 1997. It also presents the results of Wilcoxon/ Mann-Whitney median equality test between the proxies before and after 1994 (p-values in parentheses). Finally, it displays proportion of firms that display an increase in the degree of internationalization proxies, and the test of significance of this proportion ( $\mathrm{p}$-values in parentheses).

\begin{tabular}{|c|c|c|c|c|c|c|c|}
\hline Variable & Obs. & $\begin{array}{l}\text { Mean } \\
\text { (Median) } \\
\text { Before }\end{array}$ & $\begin{array}{l}\text { Mean } \\
\text { (Median) } \\
\text { After }\end{array}$ & $\begin{array}{l}\text { Mean } \\
\text { (Median) } \\
\text { Change }\end{array}$ & $\begin{array}{l}\text { Wilcoxon/ } \\
\text { Mann- } \\
\text { Whitney } \\
\text { median } \\
\text { equality test } \\
\text { (p-value) } \\
\end{array}$ & $\begin{array}{l}\text { Percentage of } \\
\text { firms that } \\
\text { changed as } \\
\text { predicted }\end{array}$ & $\begin{array}{l}\text { Sign (exact } \\
\text { binomial) } \\
\text { proportion test } \\
\text { that } p=0.5 \\
\text { (p-value) }\end{array}$ \\
\hline \multicolumn{8}{|c|}{ All companies } \\
\hline Employees & 5062 & $\begin{array}{l}1.7331 \\
(0.2670)\end{array}$ & $\begin{array}{l}2.2299 \\
(0.3650)\end{array}$ & $\begin{array}{l}0.4968 \\
(0.0980)\end{array}$ & $\begin{array}{l}4.5578^{* * *} \\
(0.0000)\end{array}$ & $25.54 \%$ & $\begin{array}{l}3732^{* * * *} \\
(0.0000)\end{array}$ \\
\hline Tobin's Q & 4347 & $\begin{array}{l}1.7425 \\
(1.4004)\end{array}$ & $\begin{array}{l}1.6617 \\
(1.3888)\end{array}$ & $\begin{array}{l}-0.0808 \\
(-0.0115)\end{array}$ & $\begin{array}{l}0.9055 \\
(0.3652)\end{array}$ & $56.94 \%$ & $\begin{array}{l}2301^{* * *} \\
(0.0000)\end{array}$ \\
\hline \multicolumn{8}{|l|}{ Materials } \\
\hline Employees & 274 & $\begin{array}{l}3.5943 \\
(1.5285)\end{array}$ & $\begin{array}{l}3.5080 \\
(1.5000)\end{array}$ & $\begin{array}{l}-0.0863 \\
(-0.0285)\end{array}$ & $\begin{array}{l}0.4896 \\
(0.6244)\end{array}$ & $40.96 \%$ & $\begin{array}{l}160^{* * * *} \\
(0.0035)\end{array}$ \\
\hline Tobin's Q & 265 & $\begin{array}{l}1.6161 \\
(1.4726)\end{array}$ & $\begin{array}{l}1.5342 \\
(1.4005)\end{array}$ & $\begin{array}{l}-0.0819 \\
(-0.0721)\end{array}$ & $\begin{array}{l}1.3382 \\
(0.1808)\end{array}$ & $44.49 \%$ & $\begin{array}{l}136^{*} \\
(0.0965)\end{array}$ \\
\hline \multicolumn{8}{|c|}{ Consumer Discretionary } \\
\hline Employees & 948 & $\begin{array}{l}3.1810 \\
(1.1190)\end{array}$ & $\begin{array}{l}4.2588 \\
(1.5175)\end{array}$ & $\begin{array}{l}1.0778 \\
(0.3985)\end{array}$ & $\begin{array}{l}3.4355^{* * *} \\
(0.0006)\end{array}$ & $29.68 \%$ & $\begin{array}{l}642^{* * *} \\
(0.0000)\end{array}$ \\
\hline Tobin's Q & 928 & $\begin{array}{l}1.8637 \\
(1.5897)\end{array}$ & $\begin{array}{l}1.5502 \\
(1.3863)\end{array}$ & $\begin{array}{l}-0.3135 \\
(-0.2034)\end{array}$ & $\begin{array}{l}7.3628^{* * *} \\
(0.0000)\end{array}$ & $39.53 \%$ & $\begin{array}{l}520^{* * * *} \\
(0.0000)\end{array}$ \\
\hline \multicolumn{8}{|c|}{ Consumer Staples } \\
\hline Employees & 169 & $\begin{array}{l}6.4168 \\
(1.2000)\end{array}$ & $\begin{array}{l}7.3322 \\
(1.4710)\end{array}$ & $\begin{array}{l}0.9154 \\
(0.2710)\end{array}$ & $\begin{array}{l}0.8789 \\
(0.3794)\end{array}$ & $35.19 \%$ & $\begin{array}{l}105^{* * *} \\
(0.0002)\end{array}$ \\
\hline Tobin's Q & 168 & $\begin{array}{l}1.9564 \\
(1.6968)\end{array}$ & $\begin{array}{l}1.9730 \\
(1.6090)\end{array}$ & $\begin{array}{l}0.0166 \\
(-0.0877)\end{array}$ & $\begin{array}{l}0.0466 \\
(0.9628)\end{array}$ & $55.35 \%$ & $\begin{array}{l}88 \\
(0.2043)\end{array}$ \\
\hline \multicolumn{8}{|l|}{ Health Care } \\
\hline Employees & 435 & $\begin{array}{l}0.7970 \\
(0.1530)\end{array}$ & $\begin{array}{l}1.2466 \\
(0.2310)\end{array}$ & $\begin{array}{l}0.4496 \\
(0.0780)\end{array}$ & $\begin{array}{l}3.6371^{* * *} \\
(0.0003)\end{array}$ & $20.19 \%$ & $\begin{array}{l}332^{* * *} \\
(0.0000)\end{array}$ \\
\hline Tobin's Q & 429 & $\begin{array}{l}2.8917 \\
(2.4324)\end{array}$ & $\begin{array}{l}2.7150 \\
(2.1254)\end{array}$ & $\begin{array}{l}-0.1767 \\
(-0.3070)\end{array}$ & $\begin{array}{l}1.8542^{*} \\
(0.0637)\end{array}$ & $48.21 \%$ & $\begin{array}{l}203 \\
(0.5115)\end{array}$ \\
\hline \multicolumn{8}{|l|}{ Energy } \\
\hline Employees & 221 & $\begin{array}{l}0.9938 \\
(0.1100)\end{array}$ & $\begin{array}{l}1.3503 \\
(0.1530)\end{array}$ & $\begin{array}{l}0.3565 \\
(0.0430)\end{array}$ & $\begin{array}{l}1.2824 \\
(0.1997)\end{array}$ & $25.23 \%$ & $\begin{array}{l}163^{\text {*** }} \\
(0.0000)\end{array}$ \\
\hline Tobin's Q & 208 & $\begin{array}{l}1.4668 \\
(1.3088)\end{array}$ & $\begin{array}{l}1.8327 \\
(1.6033)\end{array}$ & $\begin{array}{l}0.3660 \\
(0.2945)\end{array}$ & $\begin{array}{l}6.1131^{* * *} \\
(0.0000)\end{array}$ & $71.07 \%$ & $\begin{array}{l}140^{* * *} \\
(0.0000)\end{array}$ \\
\hline \multicolumn{8}{|l|}{ Financials } \\
\hline Employees & 1289 & $\begin{array}{l}0.3852 \\
(0.0000)\end{array}$ & $\begin{array}{l}0.4995 \\
(0.0000)\end{array}$ & $\begin{array}{l}0.1142 \\
(0.0000)\end{array}$ & $\begin{array}{l}0.6344 \\
(0.5258)\end{array}$ & $8.46 \%$ & $\begin{array}{l}1169^{* * *} \\
(0.0000)\end{array}$ \\
\hline Tobin's Q & 838 & $\begin{array}{l}1.1108 \\
(1.0307)\end{array}$ & $\begin{array}{l}1.1787 \\
(1.1291)\end{array}$ & $\begin{array}{l}0.0679 \\
(0.0984)\end{array}$ & $\begin{array}{l}16.6378^{* * * *} \\
(0.0000)\end{array}$ & $84.39 \%$ & $\begin{array}{l}665^{* * *} \\
(0.0000)\end{array}$ \\
\hline \multicolumn{8}{|l|}{ Industrials } \\
\hline Employees & 745 & $\begin{array}{l}2.5824 \\
(0.7030)\end{array}$ & $\begin{array}{l}3.4844 \\
(1.0745)\end{array}$ & $\begin{array}{l}0.9020 \\
(0.3715)\end{array}$ & $\begin{array}{l}3.5700^{* * * *} \\
(0.0004)\end{array}$ & $28.21 \%$ & $\begin{array}{l}514^{* * *} \\
(0.0000)\end{array}$ \\
\hline Tobin's Q & 730 & $\begin{array}{l}1.6844 \\
(1.4657)\end{array}$ & $\begin{array}{l}1.6849 \\
(1.4988)\end{array}$ & $\begin{array}{l}0.0005 \\
(0.0331)\end{array}$ & $\begin{array}{l}1.3936 \\
(0.1634)\end{array}$ & $52.21 \%$ & $\begin{array}{l}354 \\
(0.2654)\end{array}$ \\
\hline \multicolumn{8}{|c|}{ Information Technology } \\
\hline Employees & 549 & $\begin{array}{l}1.1421 \\
(0.3130)\end{array}$ & $\begin{array}{l}1.7586 \\
(0.4380)\end{array}$ & $\begin{array}{l}0.6165 \\
(0.1250)\end{array}$ & $\begin{array}{l}3.5988^{* * *} \\
(0.0003)\end{array}$ & $27.86 \%$ & $\begin{array}{l}378^{* * *} \\
(0.0000)\end{array}$ \\
\hline Tobin’s Q & 546 & $\begin{array}{l}2.2914 \\
(1.8723)\end{array}$ & $\begin{array}{l}2.1641 \\
(1.7782)\end{array}$ & $\begin{array}{l}-0.1273 \\
(-0.0941)\end{array}$ & $\begin{array}{l}0.4714 \\
(0.6373)\end{array}$ & $52.58 \%$ & $\begin{array}{l}265 \\
(0.2654)\end{array}$ \\
\hline
\end{tabular}


Table VI: continued

\begin{tabular}{|c|c|c|c|c|c|c|c|}
\hline Variable & Obs. & $\begin{array}{l}\begin{array}{l}\text { Mean } \\
\text { (Median) } \\
\text { Before }\end{array} \\
\end{array}$ & $\begin{array}{l}\begin{array}{l}\text { Mean } \\
\text { (Median) } \\
\text { After }\end{array} \\
\end{array}$ & $\begin{array}{l}\begin{array}{l}\text { Mean } \\
\text { (Median) } \\
\text { Change }\end{array} \\
\end{array}$ & $\begin{array}{l}\text { Wilcoxon/ } \\
\text { Mann- } \\
\text { Whitney } \\
\text { median } \\
\text { equality test } \\
\text { (p-value) } \\
\end{array}$ & $\begin{array}{l}\text { Percentage of } \\
\text { firms that } \\
\text { changed as } \\
\text { predicted }\end{array}$ & $\begin{array}{l}\text { Sign (exact } \\
\text { binomial) } \\
\text { proportion test } \\
\text { that } p=0.5 \\
\text { (p-value) }\end{array}$ \\
\hline \multicolumn{8}{|c|}{ Telecommunication Services } \\
\hline Employees & 82 & $\begin{array}{l}6.8179 \\
(1.0400)\end{array}$ & $\begin{array}{l}6.6402 \\
(1.9000)\end{array}$ & $\begin{array}{l}-0.1777 \\
(0.8600)\end{array}$ & $\begin{array}{l}0.5033 \\
(0.6148)\end{array}$ & $46.91 \%$ & $\begin{array}{l}43 \\
(0.6570)\end{array}$ \\
\hline Tobin's Q & 76 & $\begin{array}{l}1.8501 \\
(1.5896)\end{array}$ & $\begin{array}{l}1.6346 \\
(1.5547)\end{array}$ & $\begin{array}{l}-0.2155 \\
(-0.0349)\end{array}$ & $\begin{array}{l}0.0940 \\
(0.9251)\end{array}$ & $55.56 \%$ & $\begin{array}{l}40 \\
(0.4096)\end{array}$ \\
\hline \multicolumn{8}{|l|}{ Utilities } \\
\hline Employees & 165 & $\begin{array}{l}3.2154 \\
(2.1320)\end{array}$ & $\begin{array}{l}2.8088 \\
(1.7070)\end{array}$ & $\begin{array}{l}-0.4066 \\
(-0.4250)\end{array}$ & $\begin{array}{l}1.9321^{*} \\
(0.0533)\end{array}$ & $69.14 \%$ & $\begin{array}{l}112^{* * *} \\
(0.0000)\end{array}$ \\
\hline Tobin's Q & 161 & $\begin{array}{l}1.2162 \\
(1.2038)\end{array}$ & $\begin{array}{l}1.2782 \\
(1.2541)\end{array}$ & $\begin{array}{l}0.0620 \\
(0.0502)\end{array}$ & $\begin{array}{l}3.9711^{* * *} \\
(0.0001)\end{array}$ & $70.86 \%$ & $\begin{array}{l}107^{* * * *} \\
(0.0000)\end{array}$ \\
\hline
\end{tabular}

*** denotes $1 \%$ significance, $* *$ denotes $5 \%$ significance, and $*$ denotes $10 \%$ significance levels

Table VII: Change in Firm Employment and Tobin's Q (1993-2005)

This table presents empirical results for analysis of changes in the number of employees, as well as changes in firm valuation as measured by Tobin's Q ratio for firms in the USA between 1993 and 2005. It displays the number of usable observations for each proxy variable, mean (median) before, after 1994, and change in the mean (median) between 1993 and 2005. It also presents the results of Wilcoxon/ Mann-Whitney median equality test between the proxies before and after 1994 (p-values in parentheses). Finally, it displays proportion of firms that display an increase in the degree of internationalization proxies, and the test of significance of this proportion ( $\mathrm{p}$-values in parentheses).

\begin{tabular}{|c|c|c|c|c|c|c|c|}
\hline Variable & Obs. & $\begin{array}{l}\begin{array}{l}\text { Mean } \\
\text { (Median) } \\
\text { Before }\end{array} \\
\end{array}$ & $\begin{array}{l}\begin{array}{l}\text { Mean } \\
\text { (Median) } \\
\text { After }\end{array} \\
\end{array}$ & $\begin{array}{l}\text { Mean } \\
\text { (Median) } \\
\text { Change }\end{array}$ & $\begin{array}{l}\text { Wilcoxon/ } \\
\text { Mann- } \\
\text { Whitney } \\
\text { median } \\
\text { equality test } \\
\text { (p-value) } \\
\end{array}$ & $\begin{array}{l}\text { Percentage of } \\
\text { firms that } \\
\text { changed as } \\
\text { predicted }\end{array}$ & $\begin{array}{l}\text { Sign (exact } \\
\text { binomial) } \\
\text { proportion } \\
\text { test that } p=0.5 \\
\text { (p-value) }\end{array}$ \\
\hline \multicolumn{8}{|c|}{ All companies } \\
\hline Employees & 2798 & $\begin{array}{l}2.3217 \\
(0.3430)\end{array}$ & $\begin{array}{l}3.7799 \\
(0.5210)\end{array}$ & $\begin{array}{l}1.4582 \\
(0.1780)\end{array}$ & $\begin{array}{l}3.6350^{* * *} \\
(0.0003)\end{array}$ & $28.80 \%$ & $\begin{array}{l}1958^{* * *} \\
(0.0000)\end{array}$ \\
\hline Tobin's Q & 2079 & $\begin{array}{l}1.8017 \\
(1.4502)\end{array}$ & $\begin{array}{l}1.7085 \\
(1.4420)\end{array}$ & $\begin{array}{l}-0.0932 \\
(-0.0082)\end{array}$ & $\begin{array}{l}0.3873 \\
(0.6985)\end{array}$ & $52.72 \%$ & $\begin{array}{l}1008^{* *} \\
(0.0185)\end{array}$ \\
\hline \multicolumn{8}{|l|}{ Materials } \\
\hline Employees & 149 & $\begin{array}{l}4.6006 \\
(1.9950)\end{array}$ & $\begin{array}{l}4.8597 \\
(1.9580)\end{array}$ & $\begin{array}{l}0.2591 \\
(-0.0370)\end{array}$ & $\begin{array}{l}0.6702 \\
(0.5027)\end{array}$ & $43.24 \%$ & $\begin{array}{l}84 \\
(0.1180)\end{array}$ \\
\hline Tobin's Q & 132 & $\begin{array}{l}1.6654 \\
(1.5538)\end{array}$ & $\begin{array}{l}1.5546 \\
(1.4905)\end{array}$ & $\begin{array}{l}-0.1107 \\
(-0.0633)\end{array}$ & $\begin{array}{l}1.4227 \\
(0.1548)\end{array}$ & $45.08 \%$ & $\begin{array}{l}67 \\
(0.3193)\end{array}$ \\
\hline \multicolumn{8}{|c|}{ Consumer Discretionary } \\
\hline Employees & 493 & $\begin{array}{l}4.8132 \\
(1.8000)\end{array}$ & $\begin{array}{l}8.6465 \\
(1.8700)\end{array}$ & $\begin{array}{l}3.8334 \\
(0.0700)\end{array}$ & $\begin{array}{l}0.2042 \\
(0.8382)\end{array}$ & $39.13 \%$ & $\begin{array}{l}294^{* * *} \\
(0.0000)\end{array}$ \\
\hline Tobin's Q & 418 & $\begin{array}{l}1.9757 \\
(1.6573)\end{array}$ & $\begin{array}{l}1.6595 \\
(1.4904)\end{array}$ & $\begin{array}{l}-0.3162 \\
(-0.1669)\end{array}$ & $\begin{array}{l}3.7280^{* * *} \\
(0.0002)\end{array}$ & $41.41 \%$ & $\begin{array}{l}225^{* * *} \\
(0.0009)\end{array}$ \\
\hline \multicolumn{8}{|c|}{ Consumer Staples } \\
\hline Employees & 97 & $\begin{array}{l}9.8073 \\
(1.6140)\end{array}$ & $\begin{array}{l}10.6335 \\
(0.9030)\end{array}$ & $\begin{array}{l}0.8261 \\
(-0.7110)\end{array}$ & $\begin{array}{l}1.5280 \\
(0.1265)\end{array}$ & $39.58 \%$ & $\begin{array}{l}58^{*} \\
(0.0519)\end{array}$ \\
\hline Tobin's Q & 79 & $\begin{array}{l}2.2643 \\
(2.0292)\end{array}$ & $\begin{array}{l}2.0616 \\
(1.7623)\end{array}$ & $\begin{array}{l}-0.2027 \\
(-0.2669)\end{array}$ & $\begin{array}{l}1.2136 \\
(0.2249)\end{array}$ & $47.95 \%$ & $\begin{array}{l}38 \\
(0.8151)\end{array}$ \\
\hline \multicolumn{8}{|l|}{ Health Care } \\
\hline Employees & 257 & $\begin{array}{l}1.1592 \\
(0.1530)\end{array}$ & $\begin{array}{l}2.3951 \\
(0.2760)\end{array}$ & $\begin{array}{l}1.2359 \\
(0.1230)\end{array}$ & $\begin{array}{l}1.7412^{*} \\
(0.0816)\end{array}$ & $29.92 \%$ & $\begin{array}{l}178^{* * *} \\
(0.0000)\end{array}$ \\
\hline Tobin's Q & 230 & $\begin{array}{l}3.0164 \\
(2.6382)\end{array}$ & $\begin{array}{l}2.7306 \\
(2.2299)\end{array}$ & $\begin{array}{l}-0.2858 \\
(-0.4082)\end{array}$ & $\begin{array}{l}1.7148^{*} \\
(0.0864)\end{array}$ & $44.98 \%$ & $\begin{array}{l}115 \\
(0.1664)\end{array}$ \\
\hline
\end{tabular}


Table VII: continued

\begin{tabular}{|c|c|c|c|c|c|c|c|}
\hline Variable & Obs. & 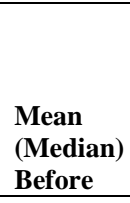 & $\begin{array}{l}\text { Mean } \\
\text { (Median) } \\
\text { After }\end{array}$ & $\begin{array}{l}\begin{array}{l}\text { Mean } \\
\text { (Median) } \\
\text { Change }\end{array} \\
\end{array}$ & $\begin{array}{l}\text { Wilcoxon/ } \\
\text { Mann- } \\
\text { Whitney } \\
\text { median } \\
\text { equality test } \\
\text { (p-value) } \\
\end{array}$ & $\begin{array}{l}\text { Percentage of } \\
\text { firms that } \\
\text { changed as } \\
\text { predicted }\end{array}$ & $\begin{array}{l}\text { Sign (exact } \\
\text { binomial) } \\
\text { proportion } \\
\text { test that } p=0.5 \\
\text { (p-value) }\end{array}$ \\
\hline \multicolumn{8}{|l|}{ Energy } \\
\hline Employees & 125 & $\begin{array}{l}0.9074 \\
(0.1540)\end{array}$ & $\begin{array}{l}1.8145 \\
(0.2540)\end{array}$ & $\begin{array}{l}0.9071 \\
(0.1000)\end{array}$ & $\begin{array}{l}1.7510^{*} \\
(0.0800)\end{array}$ & $17.89 \%$ & $\begin{array}{l}101^{* * *} \\
(0.0000)\end{array}$ \\
\hline Tobin's Q & 111 & $\begin{array}{l}1.6595 \\
(1.3691)\end{array}$ & $\begin{array}{l}2.8202 \\
(2.0329)\end{array}$ & $\begin{array}{l}1.1607 \\
(0.6637)\end{array}$ & $\begin{array}{l}5.7596^{* * *} \\
(0.0000)\end{array}$ & $74.76 \%$ & $\begin{array}{l}77^{* * * *} \\
(0.0000)\end{array}$ \\
\hline \multicolumn{8}{|l|}{ Financials } \\
\hline Employees & 759 & $\begin{array}{l}0.4047 \\
(0.0000)\end{array}$ & $\begin{array}{l}0.9316 \\
(0.0050)\end{array}$ & $\begin{array}{l}0.5270 \\
(0.0050)\end{array}$ & $\begin{array}{l}7.7777^{* * *} \\
(0.0000)\end{array}$ & $7.77 \%$ & $\begin{array}{l}688^{* * *} \\
(0.0000)\end{array}$ \\
\hline Tobin's Q & 406 & $\begin{array}{l}1.1346 \\
(1.0421)\end{array}$ & $\begin{array}{l}1.1817 \\
(1.1041)\end{array}$ & $\begin{array}{l}0.0472 \\
(0.0620)\end{array}$ & $\begin{array}{l}7.8004^{* * *} \\
(0.0000)\end{array}$ & $72.37 \%$ & $\begin{array}{l}275^{* * * *} \\
(0.0000)\end{array}$ \\
\hline \multicolumn{8}{|l|}{ Industrials } \\
\hline Employees & 415 & $\begin{array}{l}4.0336 \\
(1.0590)\end{array}$ & $\begin{array}{l}5.7232 \\
(1.2540)\end{array}$ & $\begin{array}{l}1.6895 \\
(0.1950)\end{array}$ & $\begin{array}{l}0.3427 \\
(0.7318)\end{array}$ & $40.44 \%$ & $\begin{array}{l}243^{* * *} \\
(0.0001)\end{array}$ \\
\hline Tobin's Q & 356 & $\begin{array}{l}1.7392 \\
(1.4886)\end{array}$ & $\begin{array}{l}1.7102 \\
(1.5647)\end{array}$ & $\begin{array}{l}-0.0291 \\
(0.0761)\end{array}$ & $\begin{array}{l}0.8234 \\
(0.4103)\end{array}$ & $51.83 \%$ & $\begin{array}{l}170 \\
(0.5437)\end{array}$ \\
\hline \multicolumn{8}{|c|}{ Information Technology } \\
\hline Employees & $283^{\circ}$ & $\begin{array}{l}1.5039 \\
(0.3980)\end{array}$ & $\begin{array}{l}2.8551 \\
(0.4675)\end{array}$ & $\begin{array}{l}1.3512 \\
(0.0695)\end{array}$ & $\begin{array}{l}0.4448 \\
(0.6565)\end{array}$ & $39.57 \%$ & $\begin{array}{l}168^{* * *} \\
(0.0006)\end{array}$ \\
\hline Tobin's Q & 237 & $\begin{array}{l}2.2988 \\
(1.9352)\end{array}$ & $\begin{array}{l}2.0518 \\
(1.7546)\end{array}$ & $\begin{array}{l}-0.2470 \\
(-0.1806)\end{array}$ & $\begin{array}{l}1.4821 \\
(0.1383)\end{array}$ & $41.86 \%$ & $\begin{array}{l}125^{* * *} \\
(0.0202)\end{array}$ \\
\hline \multicolumn{8}{|c|}{ Telecommunication Services } \\
\hline Employees & 24 & $\begin{array}{l}14.4720 \\
(2.2925)\end{array}$ & $\begin{array}{l}16.3518 \\
(0.4600)\end{array}$ & $\begin{array}{l}1.8797 \\
(-1.8325)\end{array}$ & $\begin{array}{l}1.9700^{* *} \\
(0.0488)\end{array}$ & $65.22 \%$ & $\begin{array}{l}15 \\
(0.2100)\end{array}$ \\
\hline Tobin's Q & 16 & $\begin{array}{l}1.6094 \\
(1.6041)\end{array}$ & $\begin{array}{l}1.5008 \\
(1.4000)\end{array}$ & $\begin{array}{l}-0.1086 \\
(-0.2041)\end{array}$ & $\begin{array}{l}1.3003 \\
(0.1935)\end{array}$ & $35.71 \%$ & $\begin{array}{l}9 \\
(0.4240)\end{array}$ \\
\hline \multicolumn{8}{|l|}{ Utilities } \\
\hline Employees & 99 & $\begin{array}{l}3.6884 \\
(2.6160)\end{array}$ & $\begin{array}{l}4.2970 \\
(2.9450)\end{array}$ & $\begin{array}{l}0.6086 \\
(0.3290)\end{array}$ & $\begin{array}{l}0.5792 \\
(0.5625)\end{array}$ & $44.21 \%$ & $\begin{array}{l}53 \\
(0.3049)\end{array}$ \\
\hline Tobin's Q & 98 & $\begin{array}{l}1.2166 \\
(1.2173)\end{array}$ & $\begin{array}{l}1.2467 \\
(1.2108)\end{array}$ & $\begin{array}{l}0.0301 \\
(-0.0065)\end{array}$ & $\begin{array}{l}0.2279 \\
(0.8197)\end{array}$ & $51.09 \%$ & $\begin{array}{l}47 \\
(0.9170)\end{array}$ \\
\hline
\end{tabular}

*** denotes $1 \%$ significance, $* *$ denotes $5 \%$ significance, and $*$ denotes $10 \%$ significance levels 
Table VIII: Results of Coefficient Equality Tests

Estimation results for equation $V_{i, t}=\sum_{\text {industry }=1}^{10} \beta_{1, i} I_{i}\left(1-D_{t}\right)+\beta_{2, i} I_{i} D_{t}+e_{i, t}$, where $\mathrm{V}$ denotes DOIINC, DOTAX, ROA, ROE, Employees, or Tobin's Q, $\mathrm{I}_{\mathrm{i}}$ denote dummies for each

industry sector $i, \mathrm{D}_{\mathrm{t}}$ equals 0 before 1994 and 1 after $1994, \beta_{1, \mathrm{i}}$ and $\beta_{2, \mathrm{i}}$ are regression coefficients, here $\beta_{1, \mathrm{i}}$ estimates pre-1994 mean values and $\beta_{2, \mathrm{i}}$ is the post-1994 mean values for the variable in question, $e_{i, t}$ denotes regression residuals, $t$-values in parentheses. The equations are estimated using panel least squares method, across all firms during $1985-2005$ period. Rows entitled "Wald test" present Chi Square statistics for tests that $\beta_{1, \mathrm{i}}=\beta_{2, \mathrm{i}}$ for industry sector $i$.

\begin{tabular}{|c|c|c|c|c|c|c|c|c|c|c|}
\hline & Materials & $\begin{array}{l}\text { Consumer } \\
\text { Discr. }\end{array}$ & $\begin{array}{l}\text { Consumer } \\
\text { Staples }\end{array}$ & Health Care & Energy & Financials & Industrials & $I T$ & $\begin{array}{l}\text { Telecom. } \\
\text { Services }\end{array}$ & Utilities \\
\hline \multicolumn{11}{|c|}{ ROA } \\
\hline \multirow[t]{2}{*}{ Pre- 1994} & $0.0645^{* * * *}$ & $0.0610^{* * *}$ & $0.0674^{* * * *}$ & $0.0710^{* * * *}$ & $0.0514^{* * *}$ & $0.0327^{* * * *}$ & $0.0622^{* * *}$ & $0.0724^{* * *}$ & $0.0599^{* * *}$ & $0.0417^{* * * *}$ \\
\hline & $(83.580)$ & (139.691) & $(69.070)$ & (86.947) & $(51.512)$ & $(63.765)$ & (127.953) & (117.794) & (43.396) & (47.008) \\
\hline \multirow[t]{2}{*}{ Post -1994} & $0.0584^{* * * *}$ & $0.0632^{* * *}$ & $0.0637^{* * * *}$ & $0.0727^{* * * *}$ & $0.0586^{* * * *}$ & $0.0246^{* * * *}$ & $0.0627^{* * *}$ & $0.0722^{* * *}$ & $0.0669^{* * * *}$ & $0.0357^{* * * *}$ \\
\hline & $(89.490)$ & $(176.560)$ & (77.119) & (116.933) & (77.855) & $(77.922)$ & (156.879) & (151.869) & (58.492) & $(42.750)$ \\
\hline Wald test & $36.7581^{* * *}$ & $15.7857^{* * *}$ & $8.7053^{* * * *}$ & $2.8162^{*}$ & $32.8446^{* * *}$ & $184.653^{* * *}$ & 0.5776 & 0.0270 & $15.3194^{* * * *}$ & $24.3995^{* * * *}$ \\
\hline \multicolumn{11}{|c|}{ ROE } \\
\hline \multirow[t]{2}{*}{ Pre- 1994} & $0.1330^{* * * *}$ & $0.1296^{* * *}$ & $0.1444^{* * *}$ & $0.1370^{* * *}$ & $0.1051^{* * * *}$ & $0.1294^{* * * *}$ & $0.1287^{* * *}$ & $0.1336^{* * *}$ & $0.1476^{* * * *}$ & $0.1284^{* * *}$ \\
\hline & (91.891) & $(159.862)$ & (79.599) & $(91.822)$ & (56.102) & (143.176) & (142.393) & (118.860) & (57.503) & (78.929) \\
\hline \multirow[t]{2}{*}{ Post -1994 } & $0.1318^{* * * *}$ & $0.1304^{* * *}$ & $0.1319^{* * * *}$ & $0.1309^{* * *}$ & $0.1286^{* * * *}$ & $0.1171^{* * * *}$ & $0.1301^{* * *}$ & $0.1283^{* * *}$ & $0.1508^{* * * *}$ & $0.1146^{* * *}$ \\
\hline & (103.973) & (188.934) & $(80.720)$ & (110.391) & (89.637) & (202.626) & (169.411) & (143.164) & (65.775) & $(72.316)$ \\
\hline \multirow[t]{2}{*}{ Wald test } & 0.4104 & 0.4992 & $26.0393^{* * *}$ & $10.1642^{* * *}$ & $99.4965^{* * *}$ & $129.646^{* * *}$ & 1.4491 & $13.5652^{* * * *}$ & 0.8687 & $37.0104^{* * * *}$ \\
\hline & \multicolumn{10}{|c|}{ ROS } \\
\hline \multirow{2}{*}{ Pre- 1994} & $0.0704^{* * * *}$ & $0.0569^{* * *}$ & $0.0564^{* * * *}$ & $0.0830^{* * *}$ & $0.0921^{* * *}$ & $0.1007^{* * *}$ & $0.0592^{* * *}$ & $0.0753^{* * *}$ & $0.1148^{* * *}$ & $0.0943^{* * *}$ \\
\hline & $(64.456)$ & (91.437) & $(40.621)$ & (73.974) & $(63.300)$ & (132.466) & $(86.510)$ & (88.766) & (58.905) & (75.556) \\
\hline \multirow[t]{2}{*}{ Post -1994 } & $0.0719^{* * * *}$ & $0.0613^{* * *}$ & $0.0605^{* * *}$ & $0.0931^{* * *}$ & $0.1053^{* * *}$ & $0.1270^{* * *}$ & $0.0656^{* * *}$ & $0.0866^{* * * *}$ & $0.1184^{* * * *}$ & $0.0850^{* * *}$ \\
\hline & $(70.272)$ & (107.986) & $(46.587)$ & $(96.170)$ & $(85.605)$ & $(255.441)$ & (104.677) & (118.484) & $(65.000)$ & $(64.660)$ \\
\hline Wald test & 1.0060 & $27.0310^{* * * *}$ & $4.5922^{* * *}$ & $46.3728^{* * * *}$ & $48.0887^{* * *}$ & $841.098^{* * * *}$ & $47.6629^{* * * *}$ & $102.638^{* * *}$ & 1.8173 & $26.6902^{* * * *}$ \\
\hline
\end{tabular}




\begin{tabular}{|c|c|c|c|c|c|c|c|c|c|c|}
\hline & Materials & $\begin{array}{l}\text { Consumer } \\
\text { Discr. }\end{array}$ & $\begin{array}{l}\text { Consumer } \\
\text { Staples }\end{array}$ & $\begin{array}{l}\text { Health } \\
\text { Care }\end{array}$ & Energy & Financials & Industrials & $I T$ & $\begin{array}{c}\text { Telecom. } \\
\text { Services }\end{array}$ & Utilities \\
\hline \multicolumn{11}{|c|}{ DOIINC } \\
\hline \multirow[t]{2}{*}{ Pre- 1994} & $0.3022^{* \text { *** }}$ & $0.2570^{* * * * *}$ & $0.2683^{* * * *}$ & $0.3023^{* * * * *}$ & $0.3173^{\text {*a*k }}$ & $0.2175^{* \text { *at }}$ & $0.2535^{* * * *}$ & $0.2947^{* * * *}$ & $0.1155^{* \text { *a* }}$ & $0.2332^{* * *}$ \\
\hline & (33.983) & (39.773) & $(20.252)$ & (29.045) & (22.660) & (13.345) & (40.197) & (40.933) & $(2.841)$ & (5.294) \\
\hline \multirow[t]{2}{*}{ Post -1994} & $0.3268^{* * *}$ & $0.2763^{* * * *}$ & $0.3686^{* * *}$ & $0.3640^{* * *}$ & $0.3743^{* * * *}$ & $0.2485^{* * *}$ & $0.2947^{* * * *}$ & $0.3123^{* * *}$ & $0.2002^{* * * *}$ & $0.1956^{* * *}$ \\
\hline & (42.129) & (50.309) & $(31.526)$ & $(42.282)$ & $(34.595)$ & (21.660) & (56.199) & (57.847) & (6.635) & $(4.030)$ \\
\hline Wald test & $4.3281^{* *}$ & $5.1874^{* *}$ & $32.1694^{* * * *}$ & $20.8900^{* * * *}$ & $10.3949^{* * * *}$ & 2.4060 & $25.2680^{* * * *}$ & $3.8308^{*}$ & $2.8047^{*}$ & 0.3293 \\
\hline \multicolumn{11}{|c|}{ DOITAX } \\
\hline \multirow[t]{2}{*}{ Pre- 1994} & $0.1815^{* * * *}$ & $0.0955^{\text {*** }}$ & $0.1190^{\text {*** }}$ & $0.1475^{* * *}$ & $0.2733^{* * *}$ & $0.0687^{* * * \pi}$ & $0.1339^{9 * * *}$ & $0.1825^{* * *}$ & 0.0137 & $0.0395^{* *}$ \\
\hline & $(28.410)$ & (28.128) & (16.374) & (23.978) & (27.334) & $(9.488)$ & (35.038) & (39.000) & $(1.344)$ & $(2.455)$ \\
\hline \multirow[t]{2}{*}{ Post -1994 } & $0.2531^{* * *}$ & $0.1177^{* * *}$ & $0.1540^{* * * *}$ & $0.1842^{* * *}$ & $0.3128^{* * * *}$ & $0.0830^{* * * *}$ & $0.1683^{* * *}$ & $0.2391^{* * * *}$ & $0.0673^{* * *}$ & $0.0520^{* * *}$ \\
\hline & $(39.455)$ & $(37.709)$ & $(21.072)$ & $(33.447)$ & $(37.283)$ & (14.973) & (47.909) & $(58.228)$ & $(5.744)$ & (3.117) \\
\hline Wald test & $62.5548^{* * *}$ & $23.1592^{* * *}$ & $11.5318^{* * *}$ & $19.6765^{* * * *}$ & $9.1586^{* * *}$ & 2.4609 & $43.9635^{* * *}$ & $82.559^{* * * *}$ & $11.9692^{* * * *}$ & 0.2890 \\
\hline \multicolumn{11}{|c|}{ Employees } \\
\hline \multirow[t]{2}{*}{ Pre- 1994} & $8.0831^{* * * * 6}$ & $10.2541^{* * * *}$ & $15.3142^{* * * \pi}$ & $5.1541^{* k \pi k}$ & $6.1621^{\text {**** }}$ & $3.7092^{* * 1}$ & $8.5376^{* * * *}$ & $5.6384^{* * * * *}$ & $22.7376^{* * * 3}$ & $4.0778^{* * *+1}$ \\
\hline & (13.665) & $(30.805)$ & $(20.521)$ & $(8.616)$ & $(8.543)$ & (9.854) & $(22.876)$ & (12.231) & $(21.203)$ & (5.793) \\
\hline \multirow[t]{2}{*}{ Post -1994 } & $8.7260^{* * * *}$ & $14.2485^{* * * *}$ & $15.0983^{* * * *}$ & $6.6692^{* * *}$ & $6.7769^{* * * *}$ & $3.4825^{* * *}$ & $10.8252^{* * *}$ & $6.6849^{* * * *}$ & $25.2611^{* * * *}$ & $5.1832^{* * *}$ \\
\hline & (14.196) & $(42.396)$ & (19.394) & (11.290) & (9.610) & (11.648) & $(28.690)$ & (15.145) & (22.734) & (6.438) \\
\hline Wald test & 0.5679 & $71.3106^{* * *}$ & 0.0401 & $3.2478^{*}$ & 0.3715 & 0.2224 & $18.5801^{* * *}$ & 2.6888 & 2.6703 & 1.0686 \\
\hline \multicolumn{11}{|c|}{ Tobin's Q } \\
\hline \multirow[t]{2}{*}{ Pre- 1994} & $1.5208^{* * *}$ & $1.6037^{* * * *}$ & $1.8271^{* * *}$ & $2.4186^{* * *}$ & $2.1672^{* * *}$ & $1.2074^{* * * \pi}$ & $1.5584^{* * * * * \pi}$ & $1.9466^{* * *}$ & $1.2862^{* * *}$ & $1.1541^{* * * *}$ \\
\hline & (42.763) & (78.933) & (39.800) & (62.219) & (47.354) & (49.523) & (69.105) & (68.539) & (19.033) & (26.717) \\
\hline \multirow[t]{2}{*}{ Post -1994 } & $1.5322^{* * * *}$ & $1.9722^{* * * *}$ & $1.9509^{* * *}$ & $2.7032^{* * *}$ & $2.7641^{* * * *}$ & $1.2085^{* * *}$ & $1.9712^{* * * *}$ & $3.0078^{* * * *}$ & $1.7808^{* * * *}$ & $1.2263^{* * *}$ \\
\hline & (21.794) & $(50.357)$ & $(21.632)$ & $(41.690)$ & $(35.824)$ & (35.758) & $(45.214)$ & $(58.238)$ & $(13.879)$ & (13.103) \\
\hline Wald test & 0.0210 & $69.7510^{* * *}$ & 1.4980 & $14.1782^{* * * *}$ & $44.2769^{* * *}$ & 0.0007 & $70.7175^{* * *}$ & $324.16^{* * * *}$ & $11.6338^{* * * *}$ & 0.4914 \\
\hline
\end{tabular}

*** denotes $1 \%$ significance, $* *$ denotes $5 \%$ significance, and $*$ denotes $10 \%$ significance levels 
Table IX: NAFTA and Firm Performance (Industry Evidence)

This table presents estimation results for equations (2) and (3) using pooled least squares regression model for 1985-2005. The dependent variable is a measure of firm performance. The standard errors are computed using diagonal White method.

Panel A: Degree of Internationalization

\begin{tabular}{|c|c|c|c|c|c|c|c|c|}
\hline \multirow[b]{2}{*}{ NAFTA } & \multicolumn{2}{|l|}{ DOIINC } & \multicolumn{2}{|c|}{ DOITAX } & \multicolumn{2}{|l|}{ DOIINC } & \multicolumn{2}{|c|}{ DOITAX } \\
\hline & 0.0216 & $(0.069)$ & 0.0173 & $(0.032)$ & & & & \\
\hline NAFTA*MATERIALS & & & & & 0.0214 & $(0.224)$ & 0.0592 & $(0.000)$ \\
\hline NAFTA*CONSUMER DISCRETIONARY & & & & & 0.0022 & $(0.884)$ & -0.0024 & $(0.799)$ \\
\hline NAFTA*CONSUMER STAPLES & & & & & 0.0365 & $(0.119)$ & 0.0036 & $(0.795)$ \\
\hline NAFTA*HEALTH CARE & & & & & 0.0626 & $(0.001)$ & 0.0096 & $(0.460)$ \\
\hline NAFTA*ENERGY & & & & & 0.0310 & $(0.217)$ & -0.0058 & $(0.792)$ \\
\hline NAFTA*FINANCIALS & & & & & 0.0138 & $(0.583)$ & -0.0476 & $(0.000)$ \\
\hline NAFTA*INDUSTRIALS & & & & & 0.0267 & $(0.061)$ & 0.0140 & $(0.166)$ \\
\hline NAFTA*INFORMATION TECHNOLOGY & & & & & 0.0115 & $(0.456)$ & 0.0672 & $(0.000)$ \\
\hline NAFTA*TELECOMS & & & & & 0.0787 & $(0.082)$ & 0.0861 & $(0.000)$ \\
\hline NAFTA*UTILITIES & & & & & 0.0092 & $(0.883)$ & 0.0106 & $(0.547)$ \\
\hline FIRM SIZE & 0.0261 & $(0.000)$ & 0.0284 & $(0.000)$ & 0.0261 & $(0.000)$ & 0.0286 & $(0.000)$ \\
\hline LEVERAGE(-1) & 0.0099 & $(0.452)$ & 0.1075 & $(0.000)$ & 0.0078 & $(0.554)$ & 0.1059 & $(0.000)$ \\
\hline SDS & -0.0020 & $(0.098)$ & 0.0014 & $(0.161)$ & -0.0021 & $(0.092)$ & 0.0014 & $(0.176)$ \\
\hline INFLATION(-1) & 0.0101 & $(0.029)$ & 0.0115 & $(0.001)$ & 0.0101 & $(0.029)$ & 0.0115 & $(0.001)$ \\
\hline RGDPG(-1) & 0.0046 & $(0.037)$ & 0.0032 & $(0.041)$ & 0.0045 & $(0.038)$ & 0.0032 & $(0.042)$ \\
\hline $\mathrm{TS}(-1)$ & -0.0139 & $(0.002)$ & -0.0324 & $(0.000)$ & -0.0139 & $(0.002)$ & -0.0323 & $(0.000)$ \\
\hline $\mathrm{DP}(-1)$ & 0.0835 & $(0.000)$ & 0.1392 & $(0.000)$ & 0.0834 & $(0.000)$ & 0.1397 & $(0.000)$ \\
\hline $\operatorname{SRATE}(-1)$ & -0.0104 & $(0.002)$ & -0.0264 & $(0.000)$ & -0.0103 & $(0.002)$ & -0.0263 & $(0.000)$ \\
\hline MATERIALS & 0.0740 & $(0.067)$ & 0.0649 & $(0.021)$ & 0.0742 & $(0.073)$ & 0.0362 & $(0.208)$ \\
\hline CONSUMER DISCRETIONARY & 0.0363 & $(0.363)$ & -0.0319 & $(0.246)$ & 0.0500 & $(0.218)$ & -0.0198 & $(0.476)$ \\
\hline CONSUMER STAPLES & 0.0787 & $(0.055)$ & -0.0324 & $(0.248)$ & 0.0686 & $(0.110)$ & -0.0251 & $(0.384)$ \\
\hline HEALTH CARE & 0.1219 & $(0.003)$ & 0.0591 & $(0.033)$ & 0.0929 & $(0.026)$ & 0.0631 & $(0.026)$ \\
\hline ENERGY & 0.1146 & $(0.005)$ & 0.1365 & $(0.000)$ & 0.1078 & $(0.014)$ & 0.1509 & $(0.000)$ \\
\hline FINANCIALS & -0.0478 & $(0.248)$ & -0.1276 & $(0.000)$ & -0.0417 & $(0.350)$ & -0.0797 & $(0.006)$ \\
\hline INDUSTRIALS & 0.0579 & $(0.145)$ & 0.0319 & $(0.247)$ & 0.0544 & $(0.174)$ & 0.0326 & $(0.241)$ \\
\hline INFORMATION TECHNOLOGY & 0.1049 & $(0.008)$ & 0.1883 & $(0.000)$ & 0.1122 & $(0.005)$ & 0.1509 & $(0.000)$ \\
\hline TELECOMS & -0.0520 & $(0.284)$ & -0.1617 & $(0.000)$ & -0.0924 & $(0.042)$ & -0.2034 & $(0.000)$ \\
\hline UTILITIES & -0.0538 & $(0.280)$ & -0.1572 & $(0.000)$ & -0.0460 & $(0.468)$ & -0.1546 & $(0.000)$ \\
\hline Adjusted R-squared & 0.0640 & & 0.1199 & & 0.0643 & & 0.1218 & \\
\hline Periods & 18 & & 18 & & 18 & & 18 & \\
\hline Companies & 2651 & & 6641 & & 2656 & & 6641 & \\
\hline Total observations & 13879 & & 39478 & & 13886 & & 39478 & \\
\hline
\end{tabular}

Note: p-values in parentheses 
International Business \& Economics Research Journal-December 2010

Volume 9, Number 12

Table IX (continued)

\begin{tabular}{|c|c|c|c|c|c|c|c|c|}
\hline & ROA & & ROE & & ROA & & ROE & \\
\hline NAFTA & 0.0001 & $(0.995)$ & -0.0934 & $(0.481)$ & & & & \\
\hline NAFTA*MATERIALS & & & & & -0.0010 & $(0.946)$ & -0.1374 & $(0.192)$ \\
\hline NAFTA*CONSUMER DISCRETIONARY & & & & & 0.0165 & $(0.265)$ & -0.0568 & $(0.559)$ \\
\hline NAFTA*CONSUMER STAPLES & & & & & -0.0051 & $(0.731)$ & -0.0311 & $(0.758)$ \\
\hline NAFTA*HEALTH CARE & & & & & 0.0084 & $(0.591)$ & -0.5949 & $(0.240)$ \\
\hline NAFTA*ENERGY & & & & & -0.1098 & $(0.411)$ & 0.4782 & $(0.678)$ \\
\hline NAFTA*FINANCIALS & & & & & -0.0179 & $(0.190)$ & -0.2500 & $(0.087)$ \\
\hline NAFTA*INDUSTRIALS & & & & & 0.0186 & $(0.230)$ & 0.0175 & $(0.873)$ \\
\hline NAFTA*INFORMATION TECHNOLOGY & & & & & 0.0152 & $(0.333)$ & -0.0679 & $(0.474)$ \\
\hline NAFTA*TELECOMS & & & & & 0.0301 & $(0.073)$ & -0.0116 & $(0.912)$ \\
\hline NAFTA*UTILITIES & & & & & 0.0020 & $(0.890)$ & -0.0787 & $(0.392)$ \\
\hline FIRM SIZE & -0.0156 & $(0.000)$ & -0.1041 & $(0.000)$ & -0.0157 & $(0.000)$ & -0.1050 & $(0.000)$ \\
\hline LEVERAGE(-1) & 0.0377 & $(0.000)$ & -0.0362 & $(0.307)$ & 0.0378 & $(0.000)$ & -0.0371 & $(0.299)$ \\
\hline SDS & 0.0007 & $(0.000)$ & 0.0002 & $(0.737)$ & 0.0007 & $(0.000)$ & 0.0002 & $(0.708)$ \\
\hline INFLATION(-1) & 0.0114 & $(0.159)$ & 0.0208 & $(0.679)$ & 0.0116 & $(0.162)$ & 0.0206 & $(0.680)$ \\
\hline RGDPG(-1) & 0.0028 & $(0.002)$ & 0.0124 & $(0.766)$ & 0.0029 & $(0.002)$ & 0.0128 & $(0.758)$ \\
\hline $\mathrm{TS}(-1)$ & -0.0108 & $(0.001)$ & -0.0764 & $(0.184)$ & -0.0107 & $(0.001)$ & -0.0768 & $(0.183)$ \\
\hline $\mathrm{DP}(-1)$ & 0.0131 & $(0.281)$ & -0.0312 & $(0.859)$ & 0.0145 & $(0.261)$ & -0.0274 & $(0.873)$ \\
\hline SRATE(-1) & -0.0099 & $(0.000)$ & -0.0655 & $(0.081)$ & -0.0098 & $(0.000)$ & -0.0659 & $(0.080)$ \\
\hline MATERIALS & 0.1679 & $(0.000)$ & 1.2251 & $(0.014)$ & 0.1668 & $(0.000)$ & 1.2598 & $(0.006)$ \\
\hline CONSUMER DISCRETIONARY & 0.1588 & $(0.000)$ & 1.1753 & $(0.015)$ & 0.1454 & $(0.000)$ & 1.1542 & $(0.010)$ \\
\hline CONSUMER STAPLES & 0.1696 & $(0.000)$ & 1.2830 & $(0.008)$ & 0.1712 & $(0.000)$ & 1.2458 & $(0.006)$ \\
\hline HEALTH CARE & 0.1693 & $(0.000)$ & 1.2294 & $(0.016)$ & 0.1614 & $(0.000)$ & 1.5917 & $(0.020)$ \\
\hline ENERGY & 0.3271 & $(0.000)$ & 3.0345 & $(0.001)$ & 0.4027 & $(0.002)$ & 2.6360 & $(0.043)$ \\
\hline FINANCIALS & 0.1431 & $(0.000)$ & 1.3408 & $(0.008)$ & 0.1559 & $(0.000)$ & 1.4724 & $(0.003)$ \\
\hline INDUSTRIALS & 0.1588 & $(0.000)$ & 1.1849 & $(0.014)$ & 0.1441 & $(0.000)$ & 1.1127 & $(0.012)$ \\
\hline INFORMATION TECHNOLOGY & 0.1660 & $(0.000)$ & 1.0743 & $(0.022)$ & 0.1534 & $(0.000)$ & 1.0599 & $(0.014)$ \\
\hline TELECOMS & 0.1974 & $(0.000)$ & 1.4520 & $(0.005)$ & 0.1760 & $(0.000)$ & 1.4046 & $(0.004)$ \\
\hline UTILITIES & 0.1496 & $(0.000)$ & 1.3403 & $(0.009)$ & 0.1465 & $(0.000)$ & 1.3374 & $(0.005)$ \\
\hline Adjusted R-squared & 0.0102 & & 0.0034 & & 0.0106 & & 0.0034 & \\
\hline Periods & 18 & & 18 & & 18 & & 18 & \\
\hline Companies & 10064 & & 10056 & & 10064 & & 10056 & \\
\hline Total observations & 63992 & & 63936 & & 63992 & & 63936 & \\
\hline
\end{tabular}

Note: p-values in parentheses 
Table IX (continued)

Panel C: Employment and Tobin's $Q$

\begin{tabular}{|c|c|c|c|c|c|c|c|c|}
\hline \multirow[b]{2}{*}{ NAFTA } & \multicolumn{2}{|c|}{ EMPLOYEES } & \multicolumn{2}{|c|}{ TOBINS' Q } & \multicolumn{2}{|c|}{ EMPLOYEES } & \multicolumn{2}{|c|}{ TOBINS' Q } \\
\hline & -0.4688 & $(0.489)$ & -0.1257 & $(0.094)$ & & & & \\
\hline NAFTA*MATERIALS & & & & & -1.6475 & $(0.037)$ & -0.4626 & $(0.000)$ \\
\hline NAFTA*CONSUMER DISCRETIONARY & & & & & 2.1567 & $(0.042)$ & -0.1171 & $(0.060)$ \\
\hline NAFTA*CONSUMER STAPLES & & & & & -1.7268 & $(0.252)$ & -0.4090 & $(0.000)$ \\
\hline NAFTA*HEALTH CARE & & & & & -2.1094 & $(0.007)$ & -0.1116 & $(0.337)$ \\
\hline NAFTA*ENERGY & & & & & -3.6695 & $(0.000)$ & 0.2440 & $(0.390)$ \\
\hline NAFTA*FINANCIALS & & & & & 0.5242 & $(0.485)$ & -0.5022 & $(0.000)$ \\
\hline NAFTA*INDUSTRIALS & & & & & -0.9975 & $(0.298)$ & -0.0181 & $(0.823)$ \\
\hline NAFTA*INFORMATION TECHNOLOGY & & & & & -1.9202 & $(0.027)$ & 0.5691 & $(0.000)$ \\
\hline NAFTA*TELECOMS & & & & & 0.0231 & $(0.992)$ & -0.1243 & $(0.269)$ \\
\hline NAFTA*UTILITIES & & & & & -1.5749 & $(0.034)$ & -0.3614 & $(0.000)$ \\
\hline FIRM SIZE & 7.2038 & $(0.000)$ & -0.1212 & $(0.000)$ & 7.2099 & $(0.000)$ & -0.1240 & $(0.000)$ \\
\hline LEVERAGE(-1) & 0.1129 & $(0.646)$ & 1.9737 & $(0.000)$ & 0.1143 & $(0.635)$ & 1.9760 & $(0.000)$ \\
\hline SDS & 0.0306 & $(0.000)$ & -0.0014 & $(0.558)$ & 0.0309 & $(0.000)$ & -0.0015 & $(0.534)$ \\
\hline INFLATION(-1) & -0.1955 & $(0.506)$ & -0.0518 & $(0.097)$ & -0.1897 & $(0.518)$ & -0.0526 & $(0.090)$ \\
\hline RGDPG(-1) & 0.0224 & $(0.866)$ & 0.0152 & $(0.090)$ & 0.0238 & $(0.857)$ & 0.0142 & $(0.114)$ \\
\hline $\mathrm{TS}(-1)$ & 1.4695 & $(0.000)$ & -0.1469 & $(0.000)$ & 1.4796 & $(0.000)$ & -0.1458 & $(0.000)$ \\
\hline $\mathrm{DP}(-1)$ & 0.6304 & $(0.510)$ & -0.1456 & $(0.050)$ & 0.6298 & $(0.510)$ & -0.1444 & $(0.050)$ \\
\hline SRATE(-1) & 1.1714 & $(0.000)$ & -0.1386 & $(0.000)$ & 1.1722 & $(0.000)$ & -0.1371 & $(0.000)$ \\
\hline MATERIALS & -44.669 & $(0.000)$ & 2.6887 & $(0.000)$ & -43.958 & $(0.000)$ & 2.9279 & $(0.000)$ \\
\hline CONSUMER DISCRETIONARY & -32.8349 & $(0.000)$ & 2.7933 & $(0.000)$ & -34.7364 & $(0.000)$ & 2.7975 & $(0.000)$ \\
\hline CONSUMER STAPLES & -34.0537 & $(0.000)$ & 3.0628 & $(0.000)$ & -33.2870 & $(0.000)$ & 3.2646 & $(0.000)$ \\
\hline HEALTH CARE & -35.9049 & $(0.000)$ & 3.7975 & $(0.000)$ & -34.8042 & $(0.000)$ & 3.7960 & $(0.000)$ \\
\hline ENERGY & -42.5738 & $(0.000)$ & 3.9321 & $(0.000)$ & -40.3963 & $(0.000)$ & 3.6824 & $(0.000)$ \\
\hline FINANCIALS & -53.6843 & $(0.000)$ & 2.2542 & $(0.000)$ & -54.5688 & $(0.000)$ & 2.5720 & $(0.000)$ \\
\hline INDUSTRIALS & -34.2157 & $(0.000)$ & 2.8330 & $(0.000)$ & -33.9288 & $(0.000)$ & 2.7687 & $(0.000)$ \\
\hline INFORMATION TECHNOLOGY & -34.7344 & $(0.000)$ & 3.5881 & $(0.000)$ & -33.7882 & $(0.000)$ & 3.1089 & $(0.000)$ \\
\hline TELECOMS & -36.7238 & $(0.000)$ & 2.7000 & $(0.000)$ & -37.1357 & $(0.000)$ & 2.7143 & $(0.000)$ \\
\hline UTILITIES & -56.4826 & $(0.000)$ & 2.2907 & $(0.000)$ & -55.8885 & $(0.000)$ & 2.4511 & $(0.000)$ \\
\hline Adjusted R-squared & 0.1755 & & 0.2182 & & 0.1758 & & 0.2204 & \\
\hline Periods & 18 & & 18 & & 18 & & 18 & \\
\hline Companies & 10064 & & 10056 & & 10064 & & 10056 & \\
\hline Total observations & 63992 & & 63936 & & 63992 & & 63936 & \\
\hline
\end{tabular}

Note: p-values in parentheses 
Table X: NAFTA and Firm Performance (Firm Characteristics)

This table presents estimation results for equation (4) using pooled least squares regression model for 1985-2005. The dependent variable is a measure of firm performance. The standard errors are computed using diagonal White method.

\begin{tabular}{|c|c|c|c|c|c|c|c|c|c|c|c|c|}
\hline \multirow[b]{2}{*}{ NAFTA } & \multicolumn{2}{|l|}{ DOIINC } & \multicolumn{2}{|c|}{ DOITAX } & \multicolumn{2}{|l|}{ ROA } & \multicolumn{2}{|l|}{ ROE } & \multicolumn{2}{|c|}{ EMPLOYEES } & \multicolumn{2}{|c|}{ TOBINS' Q } \\
\hline & 0.0456 & $(0.010)$ & 0.0653 & $(0.000)$ & 0.0105 & $(0.509)$ & 0.1121 & $(0.779)$ & -7.4621 & $(0.000)$ & -0.3855 & $(0.002)$ \\
\hline NAFTA*SIZE(-1) & -0.003 & $(0.172)$ & -0.011 & $(0.000)$ & 0.004 & $(0.607)$ & -0.033 & $(0.527)$ & 1.1793 & $(0.000)$ & -0.0632 & $(0.000)$ \\
\hline NAFTA*LEVERAGE(-1) & -0.0246 & $(0.358)$ & 0.0452 & $(0.010)$ & -0.1397 & $(0.408)$ & -0.1165 & $(0.809)$ & 2.2629 & $(0.007)$ & 2.5577 & $(0.000)$ \\
\hline NAFTA*SDS & -0.0135 & $(0.001)$ & -0.0159 & $(0.001)$ & -0.0005 & $(0.590)$ & 0.0021 & $(0.347)$ & -0.0411 & $(0.535)$ & 0.0018 & $(0.585)$ \\
\hline FIRM SIZE(-1) & 0.0282 & $(0.000)$ & 0.0358 & $(0.000)$ & -0.0187 & $(0.024)$ & -0.0822 & $(0.037)$ & 6.4057 & $(0.000)$ & -0.0740 & $(0.000)$ \\
\hline LEVERAGE(-1) & 0.0279 & $(0.211)$ & 0.0767 & $(0.000)$ & 0.1730 & $(0.306)$ & 0.0766 & $(0.874)$ & -2.0762 & $(0.011)$ & -0.5035 & $(0.000)$ \\
\hline SDS & 0.0108 & $(0.008)$ & 0.0168 & $(0.000)$ & 0.0012 & $(0.209)$ & -0.0019 & $(0.404)$ & 0.0716 & $(0.277)$ & -0.0034 & $(0.117)$ \\
\hline INFLATION(-1) & 0.0100 & $(0.030)$ & 0.0122 & $(0.000)$ & 0.0106 & $(0.135)$ & 0.0217 & $(0.663)$ & -0.2368 & $(0.418)$ & -0.0383 & $(0.220)$ \\
\hline RGDPG(-1) & 0.0045 & $(0.039)$ & 0.0034 & $(0.031)$ & 0.0025 & $(0.009)$ & 0.0129 & $(0.758)$ & 0.0032 & $(0.981)$ & 0.0201 & $(0.024)$ \\
\hline $\mathrm{TS}(-1)$ & -0.0142 & $(0.002)$ & -0.0333 & $(0.000)$ & -0.0104 & $(0.000)$ & -0.0802 & $(0.168)$ & 1.6092 & $(0.000)$ & -0.1532 & $(0.000)$ \\
\hline DP(-1) & 0.0835 & $(0.000)$ & 0.1425 & $(0.000)$ & 0.0099 & $(0.284)$ & -0.0245 & $(0.894)$ & 0.3569 & $(0.710)$ & -0.0905 & $(0.219)$ \\
\hline SRATE(-1) & -0.0106 & $(0.002)$ & -0.0272 & $(0.000)$ & -0.0097 & $(0.000)$ & -0.0685 & $(0.074)$ & 1.2782 & $(0.000)$ & -0.1412 & $(0.000)$ \\
\hline MATERIALS & 0.0584 & $(0.155)$ & 0.0316 & $(0.269)$ & 0.1556 & $(0.000)$ & 1.0942 & $(0.073)$ & -40.2854 & $(0.000)$ & 2.9569 & $(0.000)$ \\
\hline CONSUMER DISCRETIONARY & 0.0208 & $(0.609)$ & -0.0634 & $(0.024)$ & 0.1453 & $(0.000)$ & 1.0440 & $(0.083)$ & -28.4524 & $(0.000)$ & 3.0829 & $(0.000)$ \\
\hline CONSUMER STAPLES & 0.0635 & $(0.128)$ & -0.0653 & $(0.022)$ & 0.1579 & $(0.000)$ & 1.1511 & $(0.057)$ & -29.6280 & $(0.000)$ & 3.3212 & $(0.000)$ \\
\hline HEALTH CARE & 0.1065 & $(0.009)$ & 0.0269 & $(0.339)$ & 0.1573 & $(0.000)$ & 1.0987 & $(0.078)$ & -31.5243 & $(0.000)$ & 4.0598 & $(0.000)$ \\
\hline ENERGY & 0.0993 & $(0.017)$ & 0.1037 & $(0.001)$ & 0.3152 & $(0.000)$ & 2.9056 & $(0.002)$ & -38.2539 & $(0.000)$ & 4.1917 & $(0.000)$ \\
\hline FINANCIALS & -0.0631 & $(0.133)$ & -0.1577 & $(0.000)$ & 0.1315 & $(0.000)$ & 1.2123 & $(0.049)$ & -49.3727 & $(0.000)$ & 2.5083 & $(0.000)$ \\
\hline INDUSTRIALS & 0.0427 & $(0.291)$ & 0.0000 & $(0.999)$ & 0.1468 & $(0.000)$ & 1.0554 & $(0.078)$ & -29.8755 & $(0.000)$ & 3.0949 & $(0.000)$ \\
\hline INFORMATION TECHNOLOGY & 0.0893 & $(0.027)$ & 0.1568 & $(0.000)$ & 0.1559 & $(0.000)$ & 0.9458 & $(0.109)$ & -30.4028 & $(0.000)$ & 3.8150 & $(0.000)$ \\
\hline TELECOMS & -0.0672 & $(0.170)$ & -0.1968 & $(0.000)$ & 0.1832 & $(0.000)$ & 1.3188 & $(0.035)$ & -32.2852 & $(0.000)$ & 3.0075 & $(0.000)$ \\
\hline UTILITIES & -0.0703 & $(0.163)$ & -0.1904 & $(0.000)$ & 0.1322 & $(0.000)$ & 1.2018 & $(0.056)$ & -51.9026 & $(0.000)$ & 2.6548 & $(0.000)$ \\
\hline Adjusted R-squared & 0.0641 & & 0.1215 & & 0.0109 & & 0.003 & & 0.1766 & & 0.2276 & \\
\hline Periods & 18 & & 18 & & 18 & & 18 & & 18 & & 18 & \\
\hline Companies & 2651 & & 6641 & & 10064 & & 10056 & & 10064 & & 10056 & \\
\hline Total observations & 13879 & & 39478 & & 63992 & & 63936 & & 63992 & & 63936 & \\
\hline
\end{tabular}

Note: p-values in parentheses 


\section{NOTES}

